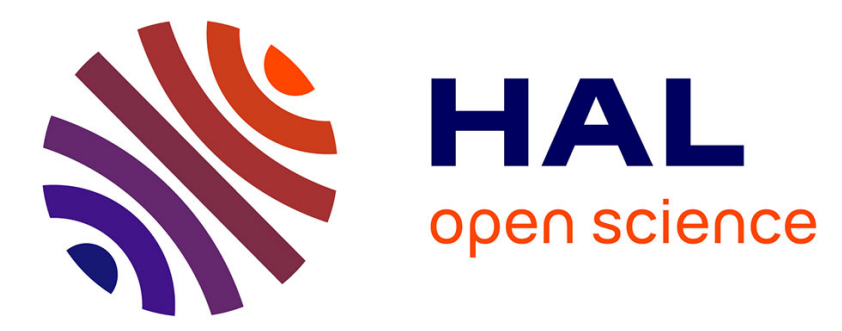

\title{
Cytogenetic screening of livestock populations in Europe: An overview
}

\author{
Alain Ducos, T. Revay, A. Kovacs, A. Hidas, Alain Pinton, Amélie \\ Bonnet-Garnier, L. Molteni, E. Slota, M.V. Arruga, W.A. van Haeringen, et
} al.

\section{To cite this version:}

Alain Ducos, T. Revay, A. Kovacs, A. Hidas, Alain Pinton, et al.. Cytogenetic screening of livestock populations in Europe: An overview. Cytogenetic and Genome Research, 2008, 120, pp.26-41. 10.1159/000118738. hal-02665416

\section{HAL Id: hal-02665416 https://hal.inrae.fr/hal-02665416}

Submitted on 31 May 2020

HAL is a multi-disciplinary open access archive for the deposit and dissemination of scientific research documents, whether they are published or not. The documents may come from teaching and research institutions in France or abroad, or from public or private research centers.
L'archive ouverte pluridisciplinaire HAL, est destinée au dépôt et à la diffusion de documents scientifiques de niveau recherche, publiés ou non, émanant des établissements d'enseignement et de recherche français ou étrangers, des laboratoires publics ou privés. 


\title{
Cytogenetic screening of livestock populations in Europe: an overview
}

\author{
A. Ducos ${ }^{a}$ T. Revay ${ }^{b} \quad$ A. Kovacs ${ }^{b} \quad$ A. Hidas ${ }^{b} \quad$ A. Pinton ${ }^{a} \quad$ A. Bonnet-Garnier ${ }^{a}$

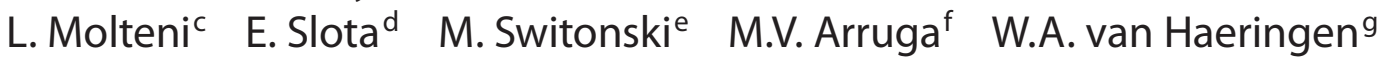 \\ I. Nicolae ${ }^{h} \quad$ R. Chaves ${ }^{i} \quad H$. Guedes-Pinto $^{i} \quad$ M. Andersson ${ }^{j} \quad$ L. lannuzzi ${ }^{k}$ \\ a INRA-ENVT, UMR 444 Génétique Cellulaire, Toulouse (France) \\ ${ }^{\mathrm{b}}$ Research Institute for Animal Breeding and Nutrition, Herceghalom (Hungary) \\ ${ }^{c}$ University of Milan, Faculty of Agricultural Sciences, Institute for Animal Sciences, Milan (Italy) \\ ${ }^{\mathrm{d}}$ National Research Institute of Animal Production, Immuno- and Cytogenetics Department, Krakow (Poland) \\ ${ }^{\mathrm{e}}$ Agricultural University, Department of Genetics and Animal Breeding, Poznan (Poland) \\ ${ }_{\mathrm{f}}^{\mathrm{f}}$ Laboratory of Cytogenetics and Molecular Genetics, Veterinary Faculty, University of Zaragoza, Zaragoza (Spain) \\ ${ }^{g}$ Dr. Van Haeringen Laboratorium BV, Wageningen (The Netherlands) \\ ${ }^{\mathrm{h}}$ Research-Development Institute for Bovine, Balotesti, Bucharest (Romania) \\ i Institute for Biotechnology and Bioengineering (IBB), Centre of Genetics and Biotechnology of the University and \\ Tras-os-Montes and Alta Douro (CGB-UTAD), Vila Real (Portugal) \\ jUniversity of Helsinki, Faculty of Veterinary Medicine, Department of Clinical Veterinary Sciences, \\ Saarentaus (Finland) \\ ${ }^{\mathrm{k}}$ National Research Council, ISPAAM, Laboratory of Animal Cytogenetics and Gene Mapping, Naples (Italy)
}

Accepted in revised form for publication by M. Schmid, 6 November 2007.

\begin{abstract}
Clinical animal cytogenetics development began in the 1960's, almost at the same time as human cytogenetics. However, the development of the two disciplines has been very different during the last four decades. Clinical animal cytogenetics reached its 'Golden Age' at the end of the 1980 's. The majority of the laboratories, as well as the main screening programs in farm animal species, presented in this review, were implemented during that period, under the guidance of some historical leaders, the first of whom was Ingemar Gustavsson. Over the past 40 years, hundreds of scientific publications reporting original chromosomal abnormalities generally associated with clinical disorders (mainly fertility impairment) have been published. Since the 1980 's, the number of scientists involved in clinical animal cytogenetics has drastically decreased for different reasons and the activities in that field are now concentrated in only a few laboratories (10 to 15, mainly in Europe), some of which have become highly specialized. Currently between 8,000
\end{abstract}

and 10,000 chromosomal analyses are carried out each year worldwide, mainly in cattle, pigs, and horses. About half of these analyses are performed in one French laboratory. Accurate estimates of the prevalence of chromosomal abnormalities in some populations are now available. For instance, one phenotypically normal pig in 200 controlled in France carries a structural chromosomal rearrangement. The frequency of the widespread 1;29 Robertsonian translocation in cattle has greatly decreased in most countries, but remains rather high in certain breeds (up to $20-25 \%$ in large beef cattle populations, even higher in some local breeds). The continuation, and in some instances the development of the chromosomal screening programs in farm animal populations allowed the implementation of new and original scientific projects, aimed at exploring some basic questions in the fields of chromosome and/or cell biology, thanks to easier access to interesting biological materials (germ cells, gametes, embryos ...).
Copyright $\odot 2008$ S. Karger AG, Basel
Request reprints from Alain Ducos

UMR INRA-ENVT 444 Génétique Cellulaire

Ecole Nationale Vétérinaire de Toulouse, 23, chemin des Capelles

BP 87614, FR-31076 Toulouse cedex 3 (France)

telephone: +33 5611932 75; fax: +33 561193924

e-mail : alain.ducos@toulouse.inra.fr
The identification of various chromosomal rearrangements in livestock species in the 1960's and 1970's (e.g. Robertsonian translocations in cattle - Gustavsson and Rockborn, 1964; Popescu, 1971; Stranzinger and Forster, 1976; reciprocal translocations in pigs - Henricson and Bäck- 
ström, 1964; Popescu and Legault, 1979) clearly associated with several clinical conditions such as intersexuality and congenital malformations as well as reproductive dysfunction (reduction of the fertility/prolificacy of the carrier animals and/or of their mates - Gustavsson, 1969, 1971; Refsdal, 1976; Popescu et al., 1984) led to the establishment of many animal cytogenetics laboratories particularly concentrated in Europe. These laboratories were created almost exclusively within academic research institutions with a focus on basic research. Under the leadership of several pioneers (e.g. Ingemar Gustavsson in Sweden, Paul Popescu in France, Gerald Stranzinger in Switzerland, Parvathi Basrur in Canada, and many other prominent researchers worldwide), the field of domestic animal cytogenetics grew rapidly during this period. The adaptation of some specialized chromosome staining techniques developed in human cytogenetics laboratories (e.g. banding techniques - Seabright, 1971; Dutrillaux et al., 1973) allowed rapid progresses in the acquisition of knowledge of the chromosomes of several animal species. An international study group with the mandate of standardizing the karyotypes of most farm animal species (including cattle, sheep, goats, pigs, horses, rabbits, swine and cats) was created in 1976 during the Reading Conference (Ford et al., 1980). The Reading standard formed the basis for all subsequent nomenclature reports (e.g. Gustavsson, 1988; ISCNDA1989, 1990; Iannuzzi, 1996; Popescu et al., 1996; Bowling et al., 1997; Ansari et al., 1999), although some discrepancies in bovid nomenclatures were identified and, for the most part, solved when both Q/G and R-banding techniques were combined with molecular markers (FISH) (Hayes et al., 2000). These preliminary karyotypes served as the basis for the construction of the most recent nomenclature of bovids (ISCNDB 2000, 2001) where cattle, sheep and goat autosomes were reported using one common chromosome nomenclature.

The research activity of the laboratories involved in animal cytogenetics reached a high level throughout the 1980's and several systematic chromosomal screening programs were initiated, mainly in continental European countries. As a result, a large number of chromosomal rearrangements were identified and reported in many scientific publications (see the reviews of Chowdhary, 1998 and Fries and Popescu, 1999, for pig and cattle, respectively). Several comprehensive review papers and textbooks were also published during this period (e.g. Gustavsson, 1980; Popescu et al., 1984; King, 1990; Long, 1991) which formed the primary reference sources for clinicians and researchers alike. In addition, the characterization of some original and rare chromosomal rearrangements led to particularly interesting scientific developments (e.g. the X;autosome reciprocal translocation identified in cattle by our Canadian colleagues - Basrur et al., 1992, 2001; Rho et al., 2007) related to the establishment of physical gene maps and understanding of basic developmental phenomena such as X-chromosome inactivation.

However, since the beginning of the nineties, a clear decline of these 'clinical' animal cytogenetics activities (identification of original chromosomal rearrangements and study of their clinical consequences in farm animals) has been noticed. The reduction in the number of scientific publications and doctoral theses in this field is one objective indicator of this evolution. Several explanations can be proposed. First, some groups initially involved in clinical animal cytogenetics were reorientated towards new scientific objectives (e.g. towards genome mapping projects). On the other hand, the eradication of particular chromosomal rearrangements in some populations made the continuation of the corresponding animal screening programs no longer justified. Finally, the retirement of some 'historical leaders' in our field and the dissolution of their laboratory groups also contributed to the decline. Currently, the number of countries in which significant clinical animal cytogenetics activities are carried out is very limited (less than ten). Most are located in Europe. Nonetheless, new initiatives adopted by several breeding and artificial insemination companies (e.g. in pigs, some companies are now interested in systematically analyzing all purebred boars at the selection level, instead of only hypoprolific boars at the production level) as well as the improvement of the techniques used in the laboratories (use of new software allowing semi-automatic karyotyping, and therefore a dramatic augmentation in the productivity of the labs) has generated a very significant increase in the number of analyses carried out in some laboratories. This was clearly the case in France. In pigs for instance, as illustrated below, the annual number of analyses carried out increased 20 -fold in only 15 years, and the number of original chromosomal rearrangements identified in this species during the 1996-2007 period in only one laboratory alone is larger than the total number of rearrangements published worldwide during the previous 30 years. The development of the few remaining laboratories allowed us to reaffirm the interest of 'clinical cytogenetics' in farm animal species, and opens new scientific opportunities in that field.

In the current paper, we present an overview of the main cytogenetic screening programs carried out in farm animal species in some currently active European cytogenetics laboratories, and summarize the main results and scientific outcomes obtained within these programs.

\section{Description of the main European screening programs}

\section{The French programs}

Only one laboratory is currently involved in large scale animal cytogenetics screening programs in France. This laboratory, located at the National Veterinary School of Toulouse, was created in 1968 by Prof. Roland Darré, assisted by Mrs Hélène Berland. It is in this laboratory that the most widespread chromosomal rearrangement in cattle (the 1;29 Robertsonian translocation) was identified for the first time in France, both in the Blonde d'Aquitaine and Limousine beef cattle breeds (Darré et al., 1972a). Screening for this particular rearrangement and diagnosis of the bovine freemartin syndrome (Darré et al., 1972b) were the main activities of the lab for many years. At the beginning of the 
Table 1. Overview of the French 1;29 Robertsonian translocation screening program in cattle

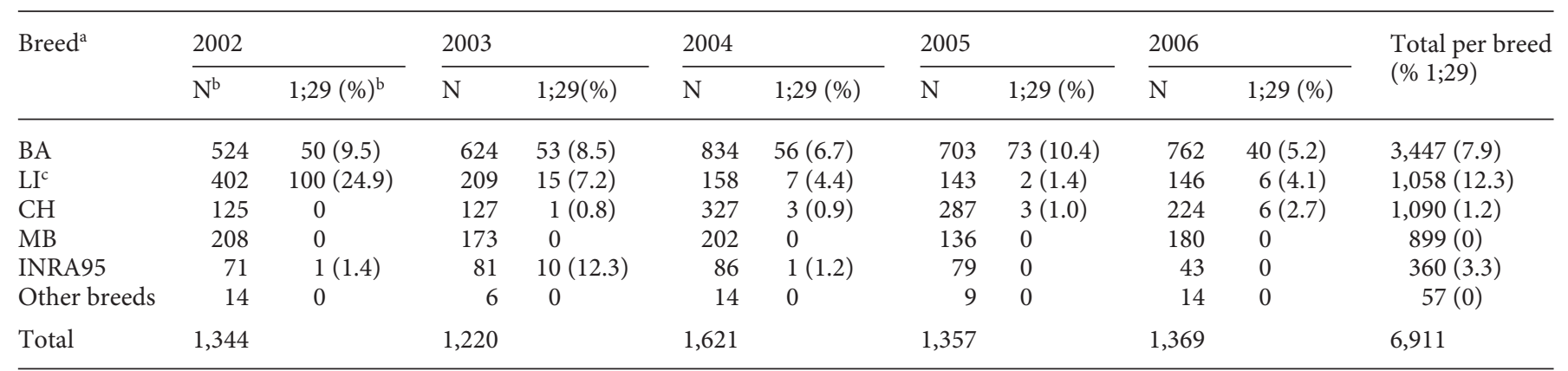

a $\quad \mathrm{BA}=$ Blonde d'Aquitaine; $\mathrm{LI}=$ Limousine; $\mathrm{CH}$ = Charolaise; $\mathrm{MB}$ = Montbéliarde; INRA95 = synthetic line; other breeds: Aubrac, Gasconne, Bazadaise.

b N: total number of animals controlled; 1;29: animals carrying the 1;29 Robertsonian translocation (both heterozygotes and homozygotes).

c The values reported in the table for the Limousine breed don't correspond to the real prevalence of the 1;29 Robertsonian translocation in this population (see the text).

1980 's, these programs were extended to include the chromosomal screening of wild pig populations (wild and breeding populations). Being located in a veterinary faculty, the laboratory also provided chromosomal analyses for hospital patients (mainly horses and dogs). However, the most important and recent evolution corresponded to the implementation of a systematic chromosomal screening program in swine. The pig clinical cytogenetics activity started in Toulouse at the beginning of the 1990's. At that time, only hypoprolific boars were karyotyped (less than 50 analyses per year). From the middle of the nineties, the majority of the French pig breeding companies (and more recently other European breeding and artificial insemination companies) started to ask for a systematic screening of all their purebred boars before using them in artificial insemination (AI) centers. With more than 2,000 pigs karyotyped annually, pig cytogenetics is currently the main component of the activity of the French laboratory (Ducos et al., 2007). The results obtained during the last five years in France are summarized below.

Screening programs in cattle. The historical 1;29 Robertsonian translocation screening program in cattle has continued without interruption until now. This program is based on a statutory obligation for the breeders to control all the young bulls before being used in AI centers. This obligation concerns all the breeds considered as 'non-free' of the translocation at the beginning of the 1980 's, i.e. mainly the beef cattle breeds (Charolaise, Limousine, Blonde d'Aquitaine) and some dairy cattle breeds (e.g. Montbéliarde). The analyses carried out only aim at detecting the 1;29 Robertsonian translocation. Therefore, simple conventional chromosome staining techniques are routinely used (GTG-banding techniques are not used systematically). About 1,300 individuals are examined annually. More than $50 \%$ of the analyses concerned animals from the Blonde d'Aquitaine breed. General statistics concerning this particular screening program for the last five years are presented in Table 1.
Only the analyses carried out for males (about $90 \%$ of the total number of analyses) are considered in Table 1. Indeed, the females examined are generally daughters (or sisters or dams) of carrier bulls. The frequency of female carriers is therefore higher than the one estimated for males. For instance, in $2006,21.5 \%$ of the females analyzed carried the translocation in the Blonde d'Aquitaine breed (121 females), $46.8 \%$ in the Limousine breed (32 females) and 25\% in the Charolaise breed (24 females).

On the other hand, the values indicated in Table 1 for the Limousine breed for years 2002-2003 do not correspond to the real prevalence of the translocation in this population. Indeed, a carrier bull was accidentally used at the beginning of year 2000. A large scale eradication program was later carried out at the request of the breeding association concerned. During years 2001, 2002 and 2003, many offspring of this bull were checked, which explains the relatively high frequencies of carrier animals during this period.

The higher prevalence of the 1;29 translocation is observed in the Blonde d'Aquitaine breed (about $8 \%$ for the 2002-2006 period). The estimated frequency sharply decreased from 1990 to 1997, then became almost stable after that date (Fig. 1).

This can be explained by the fact that only future AI bulls are systematically analyzed. Natural mating bulls generally escape the screening program, whereas this reproduction mode still represents more than $50 \%$ of the calves born in this breed. An effort should be made in this direction to eradicate the rearrangement in the Blonde d'Aquitaine population.

Complementary GTG-banding analyses are carried out when apparently abnormal chromosomes are identified using conventional staining techniques. This led to the detection of six original chromosomal rearrangements during the last five years: one 1;7 Robertsonian translocation, two mosaics for Robertsonian translocations (21;29 and 3;12), one pericentric inversion of chromosome 29 and one reciprocal translocation $(7 \mathrm{p}+; 7 \mathrm{q}-)$ in the Blonde d'Aquitaine 
Fig. 1. Evolution of the frequency of bulls carrying the 1;29 Robertsonian translocation in the Blonde d'Aquitaine beef cattle breed in France.
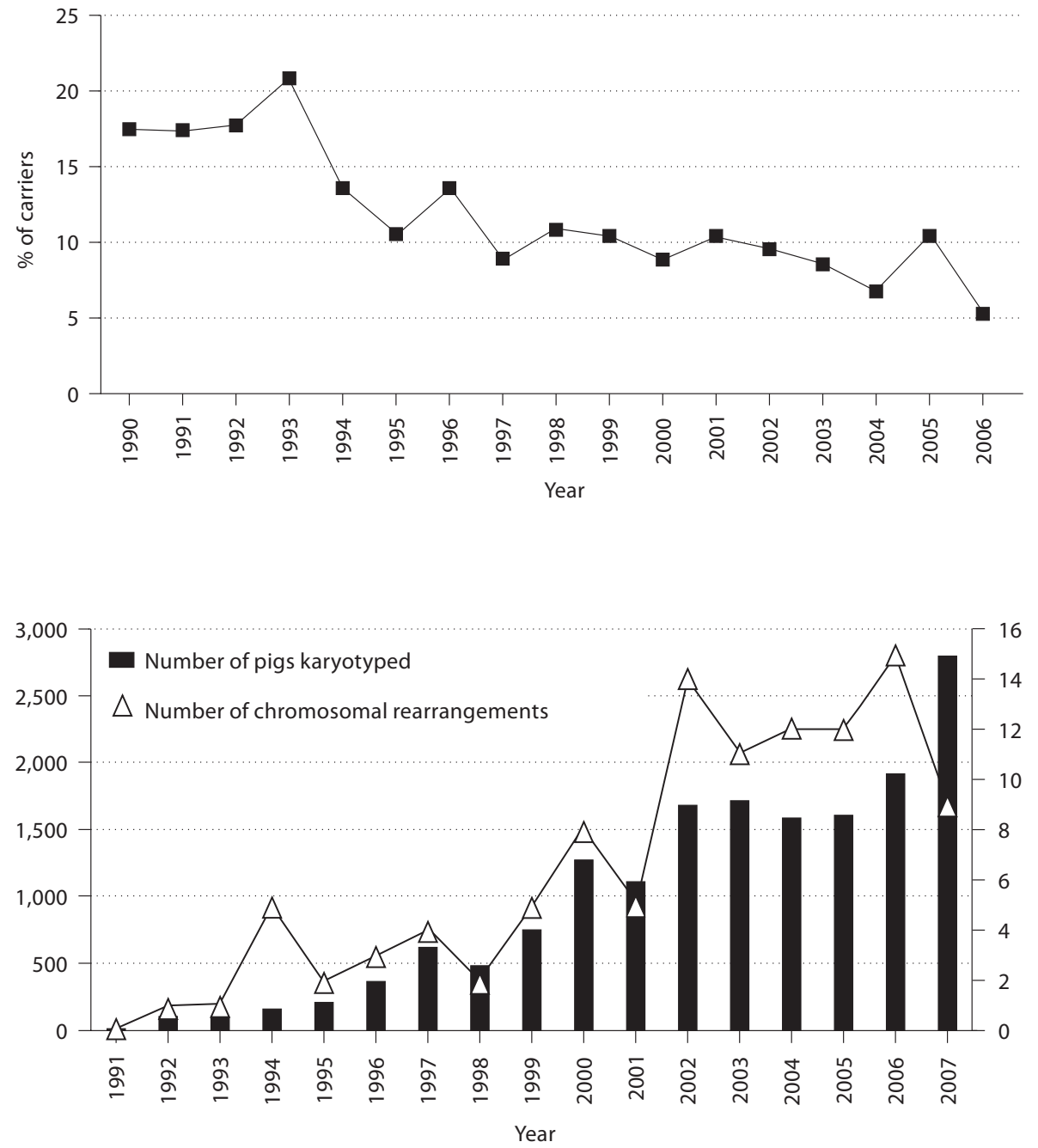

Fig. 2. Evolution of the annual number of pigs karyotyped in France and of the number of structural chromosomal rearrangements identified. For year 2007: the total number of pigs karyotyped was extrapolated from the number of pigs karyotyped from January 1st to July 1st; the number of chromosomal rearrangements indicated in the figure corresponds to the January 1st to July 1st period (only 6 months). breed; one reciprocal translocation $(1 \mathrm{q}-; 15 \mathrm{q}+)$ in the Charolaise breed. Moreover, one 61,XXY karyotype and one $60, \mathrm{XX} / 90, \mathrm{XXY}$ chimeric karyotype were identified in the Blonde d'Aquitaine breed, as well as one 60,XY/61,XYY chimeric karyotype in the Montbéliarde breed (all found in phenotypically normal young bulls). Finally, the analyses carried out in hypofertile bulls (Ducos et al., 2000) allowed the detection of two original reciprocal translocations, one involving chromosomes 9 and 12, and the other one chromosomes 8 and 21 .

About 250 analyses are carried out each year in young females born co-twin to males (diagnosis of the freemartin syndrome; 1,253 analyses since year 2002). Globally, $86.4 \%$ of these females presented an XX/XY blood chimerism (13.6\% had normal XX karyotypes).

Screening program in pigs. As mentioned above, the great majority (about $90 \%$ ) of the pigs currently screened in the Toulouse laboratory are young purebred boars waiting for an approval for use in artificial insemination (AI) centers. At the same time (2002-2007 period), 20-70 hypoprolific boars were screened annually. This represented only $3 \%$ of the total number of analyses carried out in the laboratory during this period. Finally, $7 \%$ of the analyses carried out in Toulouse during the 2002-2007 period concerned animals belonging to the families of carrier individuals: parents, (half) sibs, offspring.

The analyses carried out aim at detecting all types of chromosomal rearrangements. Therefore, GTG banding is systematically used. For some particular rearrangements the presumptive chromosomes involved and/or the location of breakpoints on the chromosomes were verified using molecular cytogenetic techniques (see for instance Ducos et al., 2002).

As of July 1st, 2007, 15,114 pigs have been karyotyped in the Toulouse laboratory with the great majority of the animals belonging to French breeding companies. As shown in Fig. 2, the number of pigs controlled has increased regularly for more than 15 years. None of these analyses were mandatory.

In total 115 original structural chromosomal rearrangements have been identified in the laboratory, including 78 since 2002 (Table 2). Sixty-six (out of 78) were reciprocal translocations and nine were peri- or paracentric inver- 
Table 2. Distribution of the constitutional structural chromosomal rearrangements identified in France during the $2002-2007^{a}$ period in pigs

\begin{tabular}{|c|c|c|c|c|c|c|c|}
\hline & \multicolumn{3}{|c|}{ Reciprocal translocations } & \multicolumn{2}{|l|}{ Inversions } & \multirow{2}{*}{$\begin{array}{l}\begin{array}{l}\text { Robertsonian } \\
\text { translocations }\end{array} \\
\text { Routine boars }\end{array}$} & \multirow[t]{2}{*}{ Total } \\
\hline & Hypoprolific boars & Routine boars ${ }^{\mathrm{b}}$ & Females & Routine boars & Females & & \\
\hline 2002 & 4 & 8 & 1 & 3 & & & 16 \\
\hline 2003 & 4 & 5 & & & & & 9 \\
\hline 2004 & 4 & 4 & 3 & 1 & 1 & & 13 \\
\hline 2005 & 4 & 6 & 1 & 2 & & 1 & 14 \\
\hline \multirow{2}{*}{$\begin{array}{l}2006 \\
2007^{\mathrm{a}}\end{array}$} & 6 & 6 & 2 & 1 & & 2 & 17 \\
\hline & & 7 & 1 & 1 & & & 9 \\
\hline Total & 22 & 36 & 8 & 8 & 1 & 3 & 78 \\
\hline a $\quad$ En & eriod: Jul & & & & & & \\
\hline
\end{tabular}

sions. For the first time since the beginning of the screening program, after more than 11,000 pigs were karyotyped, one Robertsonian translocation was identified in 2005 and two others in 2006. Also in 2006 for the first time one reciprocal translocation involving a sex chromosome was identified in an azoospermic boar: $\mathrm{t}(\mathrm{Y} ; 14)(\mathrm{q} 10 ; \mathrm{q} 11)$ (Pinton et al., 2007).

The estimated prevalence of balanced structural chromosomal rearrangements in a sample of more than 7,700 young boars karyotyped before service was $0.47 \%$ (Ducos et al., 2007). To the best of our knowledge, the pig (Sus scrofa domestica $L$.) is the only mammalian species other than humans and laboratory mice for which an accurate estimate of the prevalence of structural chromosomal rearrangements is available.

Twenty-two of the 78 rearrangements described since 2002 were identified in hypoprolific boars. All were reciprocal translocations. The estimated effect of the chromosomal rearrangements identified in hypoprolific boars since the beginning of the program (decrease of the average litter size of the mates) varied between 10 and $70 \%$ (40\% on average). One translocation, the $\mathrm{t}(3 ; 16)(\mathrm{q} 23 ; \mathrm{q} 22)$, was responsible for malformations in some of the offspring (cleft palate - Ducos et al., 2004).

Twelve cases of chimerism (XX/XY in 11 individuals, $\mathrm{XY} / \mathrm{XXY}$ in one individual) were also diagnosed. Two of these were hypoprolific boars, and three were intersex animals.

Screening program in other species. Besides cattle and swine, the Toulouse laboratory is involved in another large scale control program aimed at detecting 'domestic pig $\times$ wild pig hybrids' (having 37 chromosomes - Darré et al., 1992). Since 2002, the total number of analyses carried out in that field is 2,257. 427 animals (i.e. 18.9\%) were hybrids (37 chromosomes). This frequency was halved in 15 years.

The number of analyses carried out in horses and dogs since 2002 is very low. Only 31 horses were karyotyped, including 29 sterile and two intersex mares. Six $63, \mathrm{X}$ cases and seven 64,XY cases were diagnosed among the 29 sterile mares. All the other animals had normal karyotypes. One intersex individual presented a 64,XX karyotype, whereas the other one had a 64,XY karyotype. Only seven dogs were karyotyped. All were intersex individuals with three having a 78,XX karyotype, and four a 78,XY karyotype.

\section{The Italian program}

The Italian cytogenetic screening program concerns only bovine populations. It mainly focuses on meat breeds (mostly Chianina, Marchigiana, Romagnola and Maremmana breeds) investigated at the cytogenetics laboratory of the Animal Production Institute, University of Milan. Cytogenetic investigations have been performed in other breeds by the cytogenetic laboratories of both Milan and Naples (CNR-ISPAAM).

Most of the animals investigated (92.6\%) have been males which underwent cytogenetic analysis at about four months of age, before breed performance testing. Almost all animals were studied by using conventional Giemsa staining to detect numerical and structural (Robertsonian - rob-, and evident reciprocal - rcp-translocations) chromosome abnormalities, as well as XX/XY chimerism. Additional studies have been performed in animals carrying or suspected of carrying chromosome abnormalities. For these animals, both C- and R-banding techniques, as well as FISH-mapping studies were performed for precise identification of the chromosomes and chromosome regions involved in the abnormalities (Iannuzzi et al., 2001a, b, c; Molteni et al., 2007). Table 3 reports all investigated breeds (and animals) and all types of chromosome abnormalities identified during the last 15 years.

Some animals were found to carry both $\operatorname{rob}(1 ; 29)$ and $\mathrm{XX} / \mathrm{XY}$ chimerism. For these animals, we prefer to list them in $\mathrm{XX} / \mathrm{XY}$ chimerism because this syndrome is responsible for more deleterious effects on fertility than $\operatorname{rob}(1 ; 29)$, especially in females, also because few animals were found to be carriers of both types of chromosome anomalies.

20,030 cattle were investigated during the last 15 years (Table 3). About $90 \%$ of these analyses concerned only three meat breeds (Chianina, Marchigiana and Romagnola). In 
Table 3. Results of the chromosomal screening program carried out in Italy for ten cattle breeds during the last 15 years

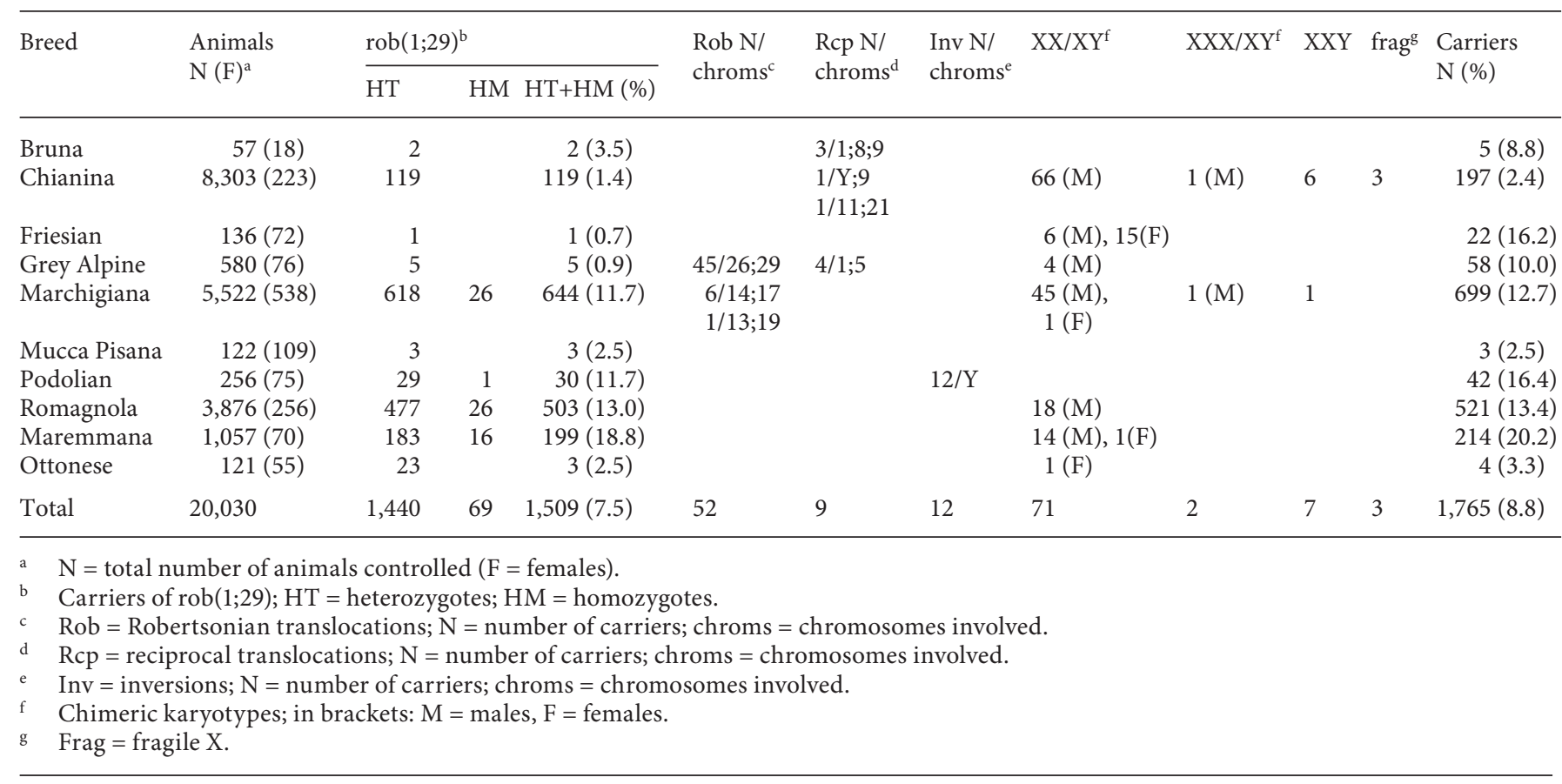

the most investigated breed (Chianina), the frequency of $\operatorname{rob}(1 ; 29)$ carriers was very low $(1.4 \%)$ although this breed is closely related to others where the translocation was found in appreciable frequencies (Marchigiana and Podolian). On the other hand, two new reciprocal translocations, involving chromosomes $\mathrm{Y}$ and 9, and 11 and 21, respectively, were identified in this breed, as well as a substantial number of $\mathrm{XX} / \mathrm{XY}$ males. In the two other highly investigated breeds (Marchigiana and Romagnola), the frequency of rob(1;29) carriers is much higher (11.7 and $13.0 \%$, respectively). Twenty-six homozygotes were even found in these two breeds. Two original Robertsonian translocations, involving chromosomes 14 and 17, and 13 and 19, respectively, were also identified in the Marchigiana breed. Among all investigated Italian breeds, the one with the highest percentage of carriers of $\operatorname{rob}(1 ; 29)$ is Maremmana $(18.8 \%)$. This breed is the closest relative of the ancient Podolian cattle living in central Europe. In this latter breed, raised in southern Italy, the frequency of rob(1;29) carriers is thus logically rather high (11.7\%). The number of investigated animals in the other breeds (Bruna, Grey Alpine, Mucca Pisana and Ottonese) is relatively limited. The frequencies of $\operatorname{rob}(1 ; 29)$ carriers are low (0.9-3.5\%). Yet, a new Robertsonian translocation involving chromosomes 26 and 29 was found in 45 animals (7.8\%) of the Grey Alpine breed. Among the various Robertsonian translocations found so far in just a few animals, the $\operatorname{rob}(26 ; 29)$ (De Giovanni et al., 1979; Di Meo et al., 2000) has the highest frequency after the rob(1;29). Moreover, BTA29 has been involved in both translocations, although these two rearrangements had different evolutionary origins (reviewed in Di Meo et al., 2006).
The frequency of rob $(1 ; 29)$ has decreased during the last 15 years due to systematic elimination of male carriers, although this chromosomal rearrangement is still present with appreciable frequencies in some breeds (Table 3), due to maternal transmission. The high frequency of carriers of chromosome abnormalities also observed in the Friesian breed (16.1\%, almost all XX/XY chimeric bulls), suggests that systematic cytogenetic screening would also be relevant in this breed, which is the most common in Italy among the milk breeds. However, the Italian Breeder's Association still does not require cytogenetic investigations for milk breeds.

The effects of Robertsonian translocations on the reproductive performance of female carriers have been investigated in the Grey Alpine and Marchigiana breeds. In the Grey Alpine breed, reproductive parameters of cows heterozygous for the rob $(26 ; 19)$ (sired by a carrier bull) were compared to the performance of cows sired by the same bull but having normal $2 \mathrm{n}=60$ karyotypes. The same experiment was carried out in the Marchigiana breed, but for the classical rob(1;29). The results showed a strong decrease of all reproductive parameters in the heterozygotes. For instance, the percentage of negative services was significantly higher in the carrier cows than in the ones having normal karyotypes (30.2 vs. $22.2 \%$ in the Grey Alpine breed, 39.9 vs. $29.6 \%$ in the Marchigiana breed). This was also the case for the percentage of irregular returns to heat and the average (inter)calving interval (414 days vs. 381 in the Grey Alpine breed, 434 days vs. 412 days in the Marchigiana breed). These results are in good agreement with results obtained in Hungary (see section 'The Hungarian programs'), and justify the continuation of the screening activities. 
Table 4. Results of the chromosomal screening program carried out in Romania for three cattle breeds during the last 20 years

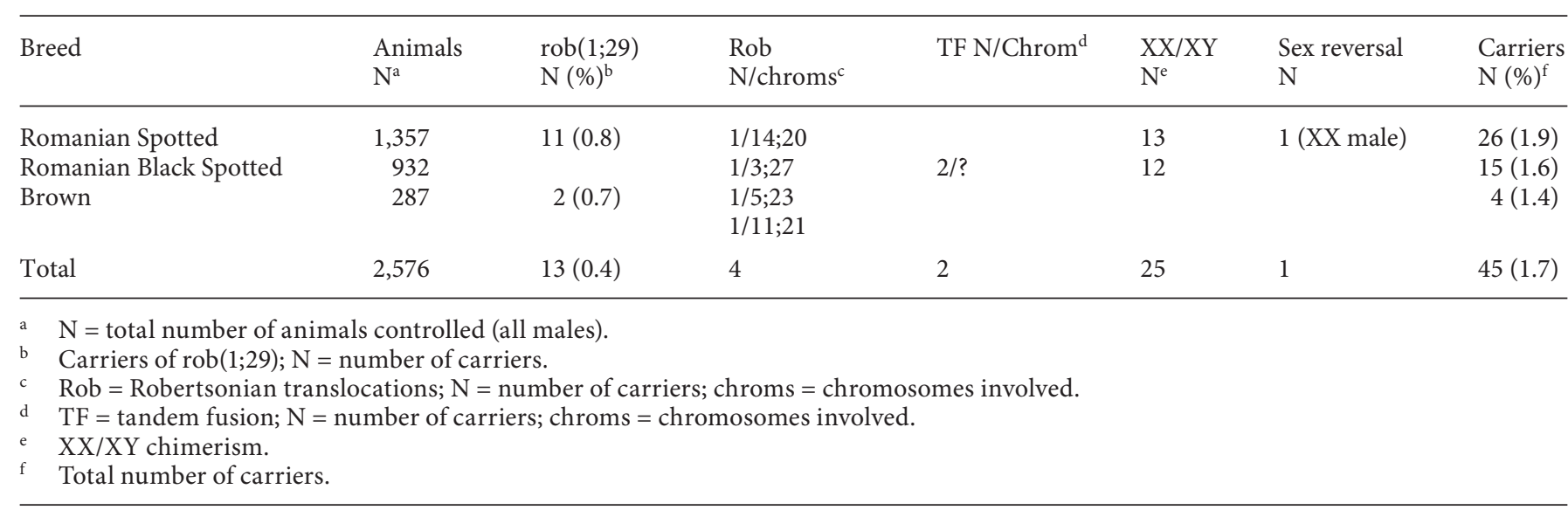

\section{The Romanian program}

Considering the great interest in the artificial insemination of cattle in Romania, chromosomal analysis mainly concerns sires. The investigated bulls mostly belonged to the Romanian Spotted, Romanian Black Spotted and Brown breeds which are the most common in the country. Overall 2,576 bulls of Romanian cattle breeds have been investigated during the last 20 years. Different types of abnormalities were identified (Table 4).

The most frequent abnormality in the screened population was XX/XY chimerism ( 25 cases). Because the opinions concerning the reproductive performance of the male carriers are relatively contradictory (Padula, 2005), their elimination is recommended.

Five original centric fusions involving chromosomes of different pairs $(1 ; 29,3 ; 27,5 ; 23,11 ; 2114 ; 20)$ have also been described (Nicolae and Popescu, 2001), but the most common was rob(1;29): 13 cases were identified, including 11 in the Romanian Spotted breed alone. This situation might be explained, on the one hand, by the high number of animals studied, or, on the other hand, by the massive import of animals and frozen semen from the Simmental breed. The carriers of Robertsonian translocations, for which negative effect on reproduction could be demonstrated, were eliminated from the herds.

One tandem fusion was identified in the Romanian Black Spotted breed (Nicolae and Livescu, 1995). The consequences regarding the reproductive performance were similar to that of the 1;29 translocation and the male carrier was therefore eliminated from the AI center.

A sex reversal constitution was identified in a bull belonging to the Romanian Spotted breed. Even if the reproductive behavior was seemingly normal, the presence of a female karyotype in this bull (XX male) justified its elimination.

A dicentric chromosome was observed in the Romanian Black Spotted breed (Nicolae, 2003). This abnormality is very rare and previously had only been identified in humans, with a very low frequency $(0.082 \%$ in the general pop- ulation; Lloyd et al., 1992). It is particularly interesting to mention that the carrier of this abnormality was born seven months after the Chernobyl nuclear accident which affected Romania. This seemed to be the only explanation for this particular chromosomal rearrangement, even if a mutation during the pregnancy should have resulted in a mosaic embryo.

\section{The Polish programs}

Screening programs in cattle. In 1989, the Ministry of Agriculture issued a directive to cytogenetically evaluate all young bulls undergoing animal breeding evaluation. Following this directive, five new local cytogenetic laboratories were established. However, the leading laboratory was the one chaired by Prof. Ewa Slota at the National Institute of Animal Production. The latest summary of this program was presented by Sysa et al. (2002) at the 15th European Cytogenetic Colloquium on Cytogenetics and Gene Mapping in Sorrento, Italy. Altogether, over 7,500 young bulls were evaluated and among them $89(1.2 \%)$ were carriers of the XX/XY chimerism and $35(0.47 \%)$ carriers of a centric fusion, mainly 1;29 in the Charolais breed (Rejduch et al., 1994) and one case of 5;22 fusion (Słota and Switonski, 1992). Also one case of the 61,XYY trisomy was diagnosed. Recently, new sex chromosome aneuploidies in young bulls were also described in the Holstein-Friesian breed: 61,XYY (Krumrych et al., 2002) and 61,XXY (Krumrych, 2003).

Since cytogenetic evaluation has also been conducted outside the national program, more cases of abnormal karyotypes have been detected (Table 5).

In addition, an indigenous cattle breed (Polish Red) was analyzed to estimate the incidence of abnormal karyotypes in this population (Slota et al., 2004). Among 451 animals investigated, three appeared to be carriers of the 1;29 Robertsonian translocation and four were carriers of the $60, \mathrm{XX} /$ 60 ,XY lymphocyte chimerism.

Cytogenetic analysis was also applied to determine the etiology of congenitally malformed calves (polymelia and 
Table 5. Abnormal karyotypes detected in Polish crossbred cattle (Polish Black and White or Polish Red and White $\times$ Holstein Friesian) subjected to cytogenetic evaluation due to fertility problems

\begin{tabular}{|c|c|c|c|}
\hline Sex & $\begin{array}{l}\text { Animals with } \\
\text { abnormal karyotype }\end{array}$ & Karyotype & Reference \\
\hline Female & 1 & $60, \mathrm{XX}, \operatorname{inv}(\mathrm{X})(\mathrm{p} 12 ; \mathrm{q} 24)$ & Switonski, 1987 \\
\hline Male & 1 & $60, X Y / 61, X Y Y$ & Jaszczak et al., 2003 \\
\hline Male & 2 & $60, \mathrm{XX} / 59, \mathrm{XY}, \operatorname{rob}(13 ; 24)$ & Slota et al., 1988 \\
\hline (freemartins) & 19 & & Nowacka et al., 2004 \\
\hline
\end{tabular}

Table 6. Cytogenetic surveys of sheep and goats bred in Poland

\begin{tabular}{|c|c|c|c|c|}
\hline Species & Total number of animals & $\begin{array}{l}\text { Chromosome } \\
\text { abnormalities }^{\mathrm{a}}\end{array}$ & $\begin{array}{l}\text { Number } \\
\text { of cases }\end{array}$ & Reference \\
\hline \multirow[t]{3}{*}{ Sheep } & 970 (random group of $50 \%$ females and $50 \%$ males) & $\mathrm{rcp}(2 \mathrm{p}+; 3 \mathrm{p}-)$ & 1 & Slota et al., 1986 \\
\hline & $\begin{array}{l}454 \text { (females of Leine breed, originating from } \\
\text { heterosexual twins) }\end{array}$ & $54, \mathrm{XX} / 54, \mathrm{XY}$ & $23(5.1 \%)$ & Szatkowska and Switonski, 1996 \\
\hline & $\begin{array}{l}104 \text { (Booroola females and males originating from } \\
48 \text { heterosexual litters) }\end{array}$ & $54, \mathrm{XX} / 54, \mathrm{XY}$ & $32(30.8 \%)$ & Keszka and Jaszczak, 1996 \\
\hline
\end{tabular}

Table 7. Large scale cytogenetic survey of pigs bred in Poland

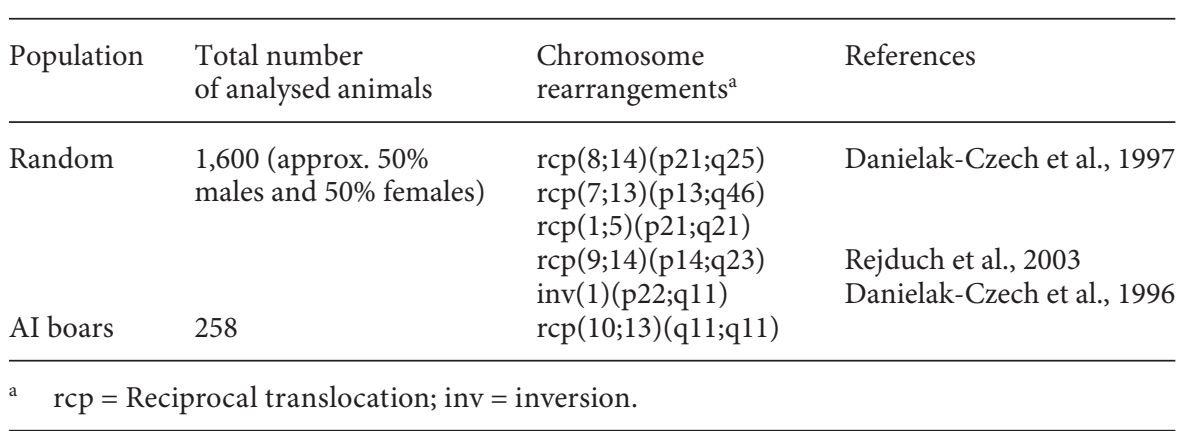

amelia). In both cases, frequent chromatid and chromosome breaks were observed (Szczerbal et al., 2006; Nowacka et al., 2007).

Screening programs in sheep and goats. These species are not systematically screened in Poland, however, a large number of animals have been analyzed (Table 6). Leukocyte chimerism $(\mathrm{XX} / \mathrm{XY})$ appeared to be the predominant chromosome abnormality.

Screening programs in pigs. Extensive cytogenetic evaluation of pigs has been performed at the National Institute of Animal Production in Balice. Two groups of animals were considered: (a) random group of 1,600 animals and (b) 258 boars from AI stations. Altogether six cases of reciprocal translocations and one case of a pericentric inversion were identified (Table 7). In earlier studies, a case of paracentric inversion of chromosome 8 was also found (Switonski, 1991).

Screening programs in horses. A cytogenetic survey of 500 young horses was performed recently by Bugno et al. (2007a). This analysis revealed that the incidence of X monosomy in mares reached $3 \%$, but no abnormalities were found in males (Table 8). Another group of mares were subjected to cytogenetic investigations due to fertility problems. Survey of such mares was performed by two groups (Table 8 ). 
Table 8. Cytogenetic surveys of horses bred in Poland

\begin{tabular}{|c|c|c|c|c|}
\hline Population & $\begin{array}{l}\text { Total number } \\
\text { of animals }\end{array}$ & Chromosome abnormalities & $\begin{array}{l}\text { Number } \\
\text { of cases }\end{array}$ & References \\
\hline $\begin{array}{l}\text { Young horses } \\
\text { (random group) }\end{array}$ & $\begin{array}{l}272 \text { (females) } \\
228 \text { (males) }\end{array}$ & $\begin{array}{l}63, \mathrm{X} \\
63, \mathrm{X} / 64, \mathrm{XX} \\
64, \mathrm{XX} / 65, \mathrm{XX},+31 \\
64, \mathrm{XX} / 64, \mathrm{XY} \\
\text { none }\end{array}$ & $\begin{array}{l}1(0.4 \%) \\
7(2.6 \%) \\
1(0.4 \%) \\
1(0.4 \%) \\
0(0 \%)\end{array}$ & $\begin{array}{l}\text { Bugno et al., 2007a } \\
\text { Bugno et al., 2007a }\end{array}$ \\
\hline
\end{tabular}

Moreover, other cases of sex chromosome aneuploidy were also reported: X monosomy (Pawlak et al., 2000), XXY trisomy (Kubien et al., 1991), X/XX/XXX mosaicism (Wieczorek et al., 2001) and XY-male pseudohermaphroditism (Switonski et al., 2005).

\section{The Dutch programs}

Screening programs in cattle. The scale of the historical 1;29 Robertsonian translocation screening program in cattle is currently relatively limited in The Netherlands. Indeed, such analyses are not mandatory for the breeders, and only limited pressure is applied by the breeding organisations to encourage cytogenetic analysis.

Screening programs in pigs. Routine karyotyping of AI boars is performed on a large scale by the Cooperative Pig Centers for Artificial Insemination in Pigs. G-banding karyotypes are carried out systematically. Up to now, more than 4,000 pigs have been karyotyped (about 1,000 per year in the recent years). At the beginning of the program, the estimated frequency of chromosomal rearrangements was higher $(1.5 \%)$ than expected from the literature. This may be due to the fact that some chromosomal aberrations were present in the populations without a specific effect on fertility, and therefore remained undetected. In recent years, the percentage of chromosomal translocations has dropped (e.g. only six confirmed translocations since 2006).

\section{The Spanish programs}

After the important observations concerning the 1;29 translocation in Sweden by I. Gustavsson and in France by P. Popescu, a systematic chromosomal control program was initiated in Spain (Zaragoza) for cattle and sheep. Table 9 summarizes the results obtained pertaining to the 1;29 Robertsonian translocation screening program in different cattle breeds (Arruga and Zarazaga, 1984, Arruga et al., 1984; Arruga, 1987).

More than $30 \%$ of the analyses have been carried out in the Holstein Friesian dairy cattle breed. No carrier individual was detected in this breed. On the other hand, a rather high frequency of carriers was observed in other breeds, as for instance the Retinta and Rubia Gallega (16.1 and $21.9 \%$, respectively), which are major beef cattle breeds in Spain. The frequency of carriers appears even higher in other breeds (up to $57.1 \%$ in the Cachena breed), but the estimated values should be considered with caution due to the very low number of animals screened.

At the same time, other cytogenetic abnormalities were detected, such as the identification of freemartinism in cattle and sheep, or deletions of chromosome 3 in sheep (e.g. Pascual and Arruga, 1996; Arruga and Pascual, 1997).

Thousands of animals were studied during the 1970's, 1980's and 1990's. However, a large decrease of these screening activities has occurred in Spain since that period. The main reasons for this decline are, on the one hand, the loss of interest in the official and private sectors, and, on the other hand, the lack of financial support for the Spanish Laboratory.

\section{The Hungarian programs}

Screening programs in cattle. Cattle chromosome investigations in Hungary were started in 1972 and since then more than 9,000 animals, mainly AI and other breeding bulls including Hungarian Grey herds (Kovacs, 1978) and relatives of carriers of different chromosome abnormalities have been evaluated (Table 10). Two hereditary abnormali- 
Table 9. Results of the 1;29 Robertsonian translocation screening program carried out in Spain

\begin{tabular}{|c|c|c|c|}
\hline Breed & $\begin{array}{l}\text { Animals } \\
\text { controlled }\end{array}$ & $\mathrm{HT}(\%)^{\mathrm{a}}$ & $\operatorname{HM}(\%)^{\mathrm{a}}$ \\
\hline Holstein Friesian & 717 & & \\
\hline Retinta & 254 & $41(16.1)$ & $3(1.2)$ \\
\hline Rubia Gallega & 146 & $32(21.9)$ & \\
\hline Parda Alpina & 89 & & \\
\hline Asturiana de los Valles & 126 & $4(3.2)$ & \\
\hline De lidia & 49 & $4(8.2)$ & \\
\hline Pirenaica & 262 & $7(2.7)$ & \\
\hline Maine-Anjou & 69 & & \\
\hline Charolaise & 72 & $1(1.4)$ & \\
\hline Alistana & 41 & $2(4.9)$ & \\
\hline Morucha & 35 & $5(14.3)$ & \\
\hline Sayaguesa & 25 & $6(24.0)$ & \\
\hline Avileña & 22 & & \\
\hline Limousine & 62 & $1(1.6)$ & \\
\hline Fleckvieh & 29 & & \\
\hline Cachena & 7 & $4(57.1)$ & \\
\hline Normande & 10 & & \\
\hline Simmental & 8 & & \\
\hline Holstein-Friesian in Morocco & 32 & & \\
\hline Rubia d'Ulmes in Morocco & 32 & $1(3.1)$ & \\
\hline Morena del Atlas in Morocco & 62 & $4(6.5)$ & \\
\hline Creole of Argentine & 25 & $1(4)$ & \\
\hline Other breeds ${ }^{\mathrm{b}}$ & 77 & & \\
\hline Total & 2,251 & $113(5.0)$ & $3(0.1)$ \\
\hline
\end{tabular}

a $\mathrm{HT}=$ heterozygotes; $\mathrm{HM}=$ homozygotes.

b Including (number of animals): Caldelana (13), Mirandesa (5), Vianesa (6), Limiana (3), Asturiana de los Montes (2), Tudanca (3), Palmeña (2), Canaria (2), Berrenda en Negro (1), Cárdena Andaluza (1), Blonde d'Aquitaine (7), Wild cattle (Doñana) (1), Blanca Cacereña (3), Blanco Azul Belga (12), Mertolenga (1), Piamontes (3) and Jersey (12).

ties have been identified: the $1 ; 29$ centric fusion in the Blonde d'Aquitaine (Kovacs and Szepeshelyi, 1987), Charolais (Kovacs and Szepeshelyi, 1987; Tozser et al., 1995), Maremmana $\times$ Hungarian Grey (Kovacs, 1989), Simmental (Kovacs and Szepeshelyi, 1987), Swedish Red and White (Gustavsson and Kovacs, 1977), and the 14;21 centric fusion in the Simmental breed (only in one AI bull and its relatives, Kovacs, 1989). In the seventies, the frequency of the 1;29 translocation carriers was $3.6 \%$ among Simmental bulls. Since 1975, all AI bulls have been karyotyped. Carriers of structural chromosome abnormalities as well as their stored semen were culled. As the calves could inherit chromosome abnormalities only from their mothers, the frequencies of those were halved in each generation. Today, the Simmental population of Hungary may be considered to be free of the 1;29 translocation. However, the 1;29 translocation was introduced into some herds of the Hungarian Grey cattle by a single Maremmana bull imported from Italy in 1971 (Kovacs, 1989). Some 720 Hungarian Grey cattle have been investigated and carriers of both sexes were culled. Currently, this ancient breed is practically free of the 1;29 translocation again. Among the 140 Belgian White-Blue bulls investigat-
Table 10. Results of the chromosomal screening of breeding bulls carried out in Hungary

\begin{tabular}{lrccc}
\hline Breed & Animals & rob(1;29) (\%) & XX/XY (\%) & Others $^{\text {a }}$ \\
\hline Holstein-Friesian & 2,885 & & $81(2.8)$ & $2(0.07)$ \\
Simmental & 858 & $26(3.0)$ & $10(1.2)$ & $2(0.2)$ \\
Hungarian Grey & 208 & $10(4.8)$ & & \\
Belgian White-Blue & 140 & & $1(1.2)$ & \\
Limousin & 84 & & & \\
Charolais & 74 & $3(4.1)$ & & \\
Hereford & 62 & & & \\
Europ. Red and White & 16 & & & \\
Blonde d'Aquitaine & 15 & $2(13.3)$ & & \\
Jersey & 10 & & & \\
Lincoln Red & 6 & & & \\
Kostroma & 2 & & & \\
Crossbred & 209 & $1(0.5)$ & $4(1.9)$ & \\
Total & 4,569 & $42(0.9)$ & $96(2.1)$ & $4(0.09)$ \\
\hline
\end{tabular}

a In Holstein-Friesian: one $\operatorname{rob}(13 ; 21)$ in mosaic form, not found among the offspring, and one XY/XXY chimeric karyotype; in Simmental: one $\operatorname{rob}(14 ; 21)$, hereditary, and one $\operatorname{rob}(5 ; 18)$ in mosaic form, not found among the offspring.

ed, none was found to be a carrier of the 1;29 translocation (Nicolas et al., 1995).

In a joint four year project with the U.S.A., examination of 69 cattle revealed the 1;29 translocation in the Charolais and Brown Swiss breeds. As well, an original 1;8;9 complex translocation in a Brown Swiss bull was identified. This difficult case was diagnosed using synaptonemal complex analysis and G-banding (Kovacs et al., 1992a). The bull had greatly reduced fertility and there were multiple lethal malformations in some of the offspring. Semen was imported to Europe (Denmark and Italy). In Denmark, insemination of 223 cows resulted in only 11 calves and the abnormality was found among them (Christensen et al., 1992). No information is available on the outcome of the importation to Italy.

The 1;29 translocation was imported from France (Blonde d'Aquitaine and Charolais breeding animals and Montbéliarde semen), Germany (Simmental breeding animals), Italy (Maremmana), Sweden (Swedish Red and White heifers) and The Netherlands (Blonde d'Aquitaine embryos). However, the last 1;29 carrier AI bull was found in 1999, and all of the 372 bulls (320 Holstein-Friesian, 42 Simmental, six Limousin, two Belgian White-Blue, one Blonde d'Aquitaine and one Polled Charolais) investigated so far in this century had normal karyotypes.

Large-scale testing of bulls allowed the identification of other chromosomal abnormalities. Two cases of Robertsonian translocations in mosaic form: $5 ; 18$ in a Simmental bull (Kovacs and Szepeshelyi, 1987) and 13;21 in a HolsteinFriesian AI bull (Kovacs et al., 1973). XX/XY chimaerism was diagnosed in more than 100 individuals of different breeds including one supposedly primary chimera singleborn Simmental bull (Kovacs et al., 1977). XXX/XY and $\mathrm{XY} / \mathrm{XXY}$ chimeric karyotypes were also identified in two bulls each. 
An exceptional opportunity to survey the losses connected to the 1;29 translocation occurred in Hungary at a large state farm (Kovacs and Csukly, 1980; Kovacs, 1989, 1994; Kovacs et al., 1992b). Almost three hundred half-sib daughters of a Simmental bull heterozygous for the 1;29 translocation were involved in a blind study (the farm had not been informed of the results of individual chromosome investigations) between 1975 and 1992. Most of the following results were confirmed by numerous studies as reviewed in Kovacs (1989). Heterozygous carrier cows had fewer but longer lactations than their half-sisters bearing the normal karyotype, with the result that the two groups had practically equivalent lifetime milk production values (Kovacs et al., 1992b; Kovacs, 1994). In the whole half-sister group, the number of $\mathrm{t}+$ individuals was lower than that of the $\mathrm{t}-\mathrm{ones}$. The difference was most apparent among cows. Among calves, the expected Mendelian distribution of 50:50 was actually almost fully observed, while there were 3.19 times more $\mathrm{t}+$ heifers among the culled ones. The insemination index (number of inseminations/pregnancy) of the $t+$ group was $28.43 \%$ higher and its fertility (pregnancies \% after the first insemination) was $32.41 \%$ lower as compared to the $\mathrm{t}$ - control group. Disadvantageous differences were found in the service period (+20.64 days) and in the ages at first breeding ( +11.86 days), in age at the first $(+30.51$ days), second (+53.03 days), third (+109.48 days) and fourth (+123.63 days) calvings, in the calving interval ( +21.62 days), in the days open (+17.16 days) as well as in the calving rate ( $-4.57 \%)$. The gestation length was the same, and the involution period was shorter by 7.79 days. This single advantage recognized was not statistically significant and was probably the effect of the higher culling rate. There were no significant differences in the occurrence of abortions and dead calves between the $\mathrm{t}+$ and $\mathrm{t}-$ control group (Kovacs et al., 1992b; Kovacs, 1994). The interval between two inseminations did not differ from the control, thus indicating a normal cycle of 20-21 days and an early preimplantation loss within the first half of the cycle. The total zygotic loss for the heterozygous carrier group was calculated to be $22.7 \%$ higher. The estimated yearly loss in Hungary connected to the 1;29 translocation was the culling of 920 heifers, $\sim 9,555$ surplus inseminations and $\sim 451$ fewer calves (Kovacs, 1989). This loss was caused by the production of gametes (and therefore embryos) with unbalanced chromosomal constitutions (Bonnet-Garnier et al., 2006, 2007).

Screening programs in other species. More than 500 artificial insemination boars were investigated for the occurrence of translocations at the G-band level. There was no positive diagnosis, possibly due to the very strict selection for litter size. Animals showing reduced prolificacy were culled very quickly, and could therefore not be subjected to chromosomal investigations. C-band polymorphism was also studied revealing sporadic occurrence of large heterochromatic blocks on the acrocentrics. This condition is suspected to be related to reduced litter size.

Large scale chromosome investigations were also carried out in pedigree stocks of poultry lines, for use in the selection procedures. Dead embryos at the early stages of incuba- tion were analysed cytogenetically to determine the potential accumulation of chromosome abnormalities in certain families or individuals. In two layer hybrid lines the proportion of embryos presenting abnormal karyotypes was estimated between 20 and 24\% (482 and 572 dead embryos analyzed, respectively - Hidas et al., 1996). Similar investigations were carried out in goose breeding stocks (Liptoi et al., 2005).

Besides the programs mentioned above, investigation of a few individuals in other farm animal species has been conducted. A 63,X mare (Bozsaky et al., 2003) as well as one case of XX-sex reversal in one polled goat (pseudomale) were found.

\section{The Portuguese programs}

Screening programs in cattle. Cytogenetic screening programs are not mandatory for the Portuguese breeders, and limited pressure is applied by the breeding organisations as already reported for the Netherlands case. This situation is not a reflection of a low incidence of the 1;29 Robertsonian translocation in Portugal. On the contrary, the translocation in many Portuguese commercial cattle breeds (e.g. Alentejana, Barrosã, Maronesa and Mirandesa) is widespread and the heterozygotes are common in these populations (Rangel-Figueiredo and Iannuzzi, 1990, 1993; Chaves et al., 2003a). It is also important to note that the highest frequency for the 1;29 Robertsonian translocation was found in a Portuguese breed (Barrosã, 6,000 animals in this population, 206 karyotyped) with $70 \%$ of individuals carrying the rob(1;29) (17\% of which were homozygous - RangelFigueiredo and Iannuzzi, 1993). Furthermore, in the Barrosã breed, two more Robertsonian translocations were detected, namely $(15 ; 25)$ (Iannuzzi et al., 1992) and $(16 ; 18)$ (Iannuzzi et al., 1993).

In the Portugese laboratory, cytogenetic screening in cattle has been conducted since 2000 , especially regarding the cattle breeds from the North of Portugal. However, these analyses are conducted for research purposes, and not because the breeders or breeding organisations request the services of the laboratory. The number of analyses carried out is therefore rather limited (about 200 animals screened in each breed). The most frequent rearrangement found is certainly the 1;29 translocation (from 9 to $77 \%$ of carriers, depending on the breed). Recently, efforts have focused on the study of the fundamental features of this chromosomal rearrangement as it constitutes an excellent chromosome model (Chaves et al., 2003a; Di Meo et al., 2006).

In addition, the involvement of chromosomal abnormalities in some congenital defects has been studied. A mixoploid (data not published) and a complex intersex condition with the existence of Y chromosome material in the two X chromosomes (Payan-Carreira et al., 2008) was found in two Holstein calves, respectively.

Screening programs in other species. Sheeps, goats and pigs are also not systematically screened in Portugal. Nevertheless, in 2003, an 8;11 translocation in a female sheep belonging to 'Churra da Terra Quente' breed was detected (Chaves et al., 2003b). 


\section{Discussion}

The aim of this paper was not to do an exhaustive survey of all published results concerning the cytogenetic screening of domestic animal populations worldwide, but rather to illustrate this activity by presenting the data obtained in eight European countries in which animal cytogenetics laboratories are active: France, Italy, Romania, Poland, The Netherlands, Spain, Hungary and Portugal. Even if a large proportion of chromosomal studies in farm animal species have been carried out in these eight countries during the last 15 years, original studies were conducted in other countries too, but usually on a more limited scale. This was for instance the case of Switzerland and Finland. In Switzerland, Tschudi (1984) reported that among the 2,941 bulls investigated between 1973 and 1984, 31 (1\%) carried the classical $\operatorname{rob}(1 ; 29)$, whereas three carried other centric fusions and 32 presented a blood XX/XY chimerism. Comparable results were obtained later (1994-2001 period): 11 bulls, mainly sons from imported (U.S.A.) semen, carrying the $\operatorname{rob}(1 ; 29)$, over 2,315 controlled ( $0.5 \%)$ - Stranzinger (unpublished results). Complementary, molecular studies carried out by Joerg et al. (2001) revealed significant molecular differences in the centromeric region of different centric fusions, and proved the very ancient origin of some of them. No systematic and large scale control program exists in Finland, but animals with reproductive problems have been occasionally studied, allowing the discovery of original chromosomal rearrangements in cattle, pigs and horses (e.g. Villagomez et al., 1993; Mäkinen et al., 1999b, 2000, 2006) (Table 11).

Similarly, studies in Canada were conducted on the effects of either the $t(1 ; 29)$ (Schmutz and Moker, 1989; Schmutz et al., 1991) or t $(14 ; 20)$ (Schmutz et al., 1997) on the karyotype of embryos from carrier parents. A small scale screening study of 134 bulls of 11 breeds detected seven $t(1 ; 29)$ carriers (Schmutz et al., 1990). In other small scale screening studies of cattle abortuses, one monosomy, seven trisomies, and one translocation were detected in 73 of the 107 samples successfully cultured and karyotyped (Coates et al., 1988; Schmutz et al., 1996).

The results presented above and in the other papers of this special issue clearly illustrate that, even if the number of scientists and laboratories involved in clinical animal cytogenetics has substantially decreased over the last 15 years, our discipline is still active, scientifically attractive and important for livestock breeders. Overall, the cytogenetic investigations carried out for a large number of AI bulls have had very positive technical and economic repercussions. On the one hand, removing the carriers from reproduction during the first year of the selection procedure avoided the dissemination of the chromosomal rearrangements in the offspring. As a consequence, the frequency of the widespread 1;29 Robertsonian translocation, for instance, has been dramatically reduced in most countries during the last 20 years. On the other hand, the costs corresponding to the complete selection procedure of the carrier animals were saved. The development of the activities in the most active laboratories largely compensates for the decrease in the number of labo-
Table 11. Chromosomal rearrangements identified in hypoprolific boars in Finland

\begin{tabular}{lll}
\hline $\begin{array}{l}\text { Reciprocal) } \\
\text { translocation }\end{array}$ & $\begin{array}{l}\text { Average } \\
\text { litter size }\end{array}$ & Reference \\
\hline$(7 \mathrm{q}-; 12 \mathrm{q}+)$ & 7.9 & Kuokkanen and Mäkinen, 1987 \\
$(7 ; 15)(\mathrm{q} 24 ; \mathrm{q} 26)$ & 5.2 & Mäkinen et al., 1997 \\
$(2 ; 9 ; 14)(\mathrm{q} 23 ; \mathrm{q} 22 ; \mathrm{q} 25)$ & 3.3 & Mäkinen et al., 1997 \\
$(1 \mathrm{p}+; 15 \mathrm{q}-)$ & 7.1 & Kuokkanen and Mäkinen, 1988 \\
$(8 ; 10)(\mathrm{p} 11 ; \mathrm{q} 13)$ & 9.0 & Mäkinen et al., 1999a \\
$(4 \mathrm{q}+; 13 \mathrm{q}-)$ & 7.4 & Mäkinen and Remes, 1986 \\
$(2 ; 4 ; 15)$ & 8.2 & \\
$(1 \mathrm{p}-; 11 \mathrm{q}+)$ & 7.8 & Kuokkanen and Mäkinen, 1988
\end{tabular}

a The first four translocations were identified in on-farm breeding boars; the last four translocations were identified in AI boars

ratories involved in that field. The recent results obtained, showing for instance that the prevalence of chromosomal rearrangements is much higher than that initially considered, at least in some species (e.g. in pigs the prevalence of structural chromosomal rearrangements is $1 / 200$, i.e. comparable to man, and not 1/1,500 as published earlier by Legault and Popescu, 1993), make the professional organizations as well as the scientific community more attentive to our work. In pigs again, the breeding and AI companies wishing to carry out systematic controls in their populations have never been so numerous as now. The perspectives of development of the different laboratories are therefore still important. In cattle for instance, one can argue that it would be very pertinent to systematically screen all the bulls used in artificial insemination (AI) centers, as already carried out for purebred boars in some countries. Such an objective should concern the beef cattle breeds, as already considered in the past in some countries, as well as the dairy cattle breeds, and especially the Holstein Friesian breed, which is numerically the most important in almost all European countries, and for which artificial insemination is nearly the only mode of reproduction which results in very high diffusion levels of genetics from selected bulls. Indeed, there is a non-negligible risk that some of the selected bulls will carry particular chromosomal rearrangements with low to moderate effects on the fertility of the mates (e.g. Robertsonian translocations or inversions). As shown in man (Anton et al., 2005; Roux et al., 2005) and verified in some animal studies (Bonnet-Garnier et al., 2006), the individuals carrying such rearrangements may produce a low proportion of unbalanced gametes (leading to early embryonic mortality). The probability of not detecting these rearrangements during the progeny testing phase of the bulls is therefore important (average fertility decrease of the mates is too low to be detected). Without cytogenetic screening, the undetected carrier animals will be used and then sire tens if not hundreds of thousands offspring. With such diffusion levels, even with low effects of the rearrangements, the economical consequences could be very substantial, and probably much more important than the global cost of the 
chromosomal screening program. The full progeny testing cost of one AI bull is approximately 40,000 euros. The cost of carrying out one karyotype is less than 100 euros. Such a disproportion between these two values should incite the breeding organizations to more systematically screen their breeding animals, especially in a context where fertility has become one of the main limiting factors of the economic efficiency of the herds, and was therefore introduced into the global selection goals of most dairy cattle breeds (Weigel, 2006). In pig production, one can also demonstrate easily that the overall cost of a chromosomal screening program is much lower than the cost of using translocation carrier males in AI stations. Indeed, considering a 1/200 incidence of reciprocal translocations in this species, the cost of detecting one particular rearrangement is about 12,000 euros $(200 \times 60$, where 60 euros is the cost of carrying out the karyotype of one animal). In contrast, the cost of using one translocated boar in an AI centre is at least 20,000 euros. Indeed, the translocation carrier boar will be used until the hypoprolificacy of his mates is detected, i.e. at least for four months. During that period, it will produce at least 160 litters $(40 /$ month). The total number of piglets lacking at the end of the 4-month period will be $640(160 \times 4$, where 4 is the average litter size reduction connected to the translocation), which corresponds to a 19,200 euros economic loss for the breeders $(640 \times 30$, where 30 euros is the economical value of one piglet). The economic loss is even much higher if we consider that the chromosomal rearrangement is carried by a purebred boar at the selection or multiplication levels of the production pyramid, as $50 \%$ of their offspring will in turn carry the rearrangement.

In Western European countries, where farmers are in a stable financial situation and the profitability of animal husbandry is better than in countries with reorganizing agricultural structures, the above mentioned facts and arguments are recognized to be easier to implement. A good example is France where almost all AI bulls (beef cattle breeds) and purebred boars are now under cytogenetic control. In contrast, governmental support of national screening programs is decreasing in a number of countries. Breeding companies and associations could incorporate the chromosome analysis into their quality control systems, which would have great marketing importance demonstrating their careful business policy.

The importance of cytogenetics in veterinary medicine needs reaffirmation. The involvement of chromosomal abnormalities in many congenital defects and cancers has been documented in man for a long time (Lejeune et al., 1959, 1963; Nowell and Hungerford, 1960). Major medical stakes justified the extraordinary development of human cytogenetics during the $20^{\text {th }}$ century (some 900,000 cytogenetic analyses are now performed each year in approximately 500 laboratories worldwide - Gersen, 1999). In humans, cytogenetic investigations are carried out systematically in cases of congenital malformations. This is far from being the case in animal species, mainly for economic reasons (the economic value of a piglet, a lamb or a calf in some breeds is lower than the cost of carrying out one karyotype). Nevertheless, the identification and characterization of particular chromosomal rearrangements paved the way for discovering many deleterious genes in humans. This approach has been almost systematically neglected in animal species. However, the improvement of the molecular cytogenetic techniques, well mastered in our laboratories now, gives us new opportunities in that field. Some recent examples in constitutional (Pinton et al., 2002; Payan-Carreira et al., 2008) and cancer animal cytogenetics (Thomas et al., 2003, 2005; Santos et al., 2006) illustrate these opportunities.

Finally, it can also be argued that farm animal species are very interesting and informative alternative models in biomedical research (Pliska and Stranzinger, 1990). They can be useful in particular to study some fundamental aspects of the cell and/or chromosome biology, as well as for evolutionary studies (Iannuzzi et al., 2000; Chaves et al., 2005; Di Meo et al., 2005; Iannuzzi, 2007). For instance, the karyotype structure of the domestic pig (Sus scrofa domestica L.) is much more similar to human than that of the mouse. The females of this species are relatively prolific (12-14 progeny per litter on average), which means that the number of oocytes or embryos that can be analysed per female is relatively high. In addition, the generation interval is relatively short (about two years), and the experimental production of individuals with particular karyotypes is possible at reasonable expense. In other animal species, as for instance bovines, the reproductive biotechnologies (e.g. ovum pick-up and in vitro fecundation, or somatic cell nuclear transfer) are well mastered, which facilitates the collection of biological material of interest. In France, these animal model species have been used to study the impact of chromosomal rearrangements on the course and products of meiosis. Some questions, very difficult to investigate in humans for technical and ethical reasons, as for instance the difference of segregation profiles between males and females, or the variability of segregation profiles between individuals having the same karyotype, or between sperm samples for the same individual, could be thoroughly documented (e.g. Pinton et al., 2005; Bonnet-Garnier et al., 2007). In Canada, the limited access to relevant foetal oocytes which precluded direct study of meiotic events in female carriers was overcome by the use of somatic cell nuclear transfer in cattle to study meiosis in a female carrying a sex-dependent fertilityimpairing X-chromosome abnormality (Rho et al., 2007). Other up to date biological questions could be investigated using these animal species, as for instance the impact of chromosomal rearrangements on the spatial organization of chromosome territories and gene expression in somatic cells, or the spatial organization of chromosome territories in the gametes. The large scale chromosomal screening programs carried out in several European countries now makes the raw material necessary for such studies available.

\section{Acknowledgements}

The authors want to thank Dr. W. Allan King for the English revision of the text, as well as the reviewers for their useful comments on the manuscript. 


\section{References}

Ansari HA, Bosma AA, Broad TE, Bunch TD, Long SE, et al: Standard G-, Q-, and R-banded ideograms of the domestic sheep (Ovis aries): homology with cattle (Bos taurus). Report of the committee for the standardization of the sheep karyotype. Cytogenet Cell Genet 87:134-142 (1999).

Anton E, Blanco J, Egozcue J, Vidal F: Sperm studies in heterozygote inversion carriers: a review. Cytogenet Genome Res 111:297-304 (2005).

Arruga MV: Chromosome analysis of 27 cattle breeds in Spain. J Dairy Sci 70 (suppl 1):237 (1987)

Arruga MV, Pascual I: Chromosome deletion identification in sheep (Ovis aries). Cytogenet Cell Genet 77:39 (1997).

Arruga MV, Zarazaga I: Frequency distribution of the Robertsonian translocation $(1 ; 29)$ in cattle populations bred in Spain. Proceedings of the $6^{\text {th }}$ European Colloquium on Cytogenetics of Domestic Animals, Zürich, Switzerland, pp 43-51 (1984).

Arruga MV, Zarazaga I, Vallejo M, Burguete I: The 1/29 Robertsonian translocation in autochthonous Spanish cattle breeds: hereditary studies in families. Proceedings of the $6^{\text {th }}$ European Colloquium on Cytogenetics of Domestic Animals, Zürich, Switzerland, pp 129-136 (1984).

Basrur PK, Pinheiro LEL, Berepubo NA, Reyes ER, Popescu CP: X chromosome inactivation in Xautosome translocation carrier cows. Genome 35:667-675 (1992).

Basrur PK, Koykul W, Baguma-Nibasheka M, King WA, Ambady S, De Leon FAP: Synaptic pattern of sex complements and sperm head malformation in X-autosome translocation carrier bulls. Mol Reprod Dev 59:66-67 (2001)

Bonnet-Garnier A, Pinton A, Berland HM, Khireddine B, Eggen A, et al: Sperm nuclei analysis of 1/29 Robertsonian translocation carrier bulls using fluorescence in situ hybridization. Cytogenet Genome Res 112:241-247 (2006)

Bonnet-Garnier A, Berland HM, Beckers JF, Lacaze S, Pinton A, et al: Meiotic segregation analysis in cows carriers of $t(1 ; 29)$ Robertsonian translocation. Chromosome Res 15 (suppl 1):148 (2007).

Bowling AT, Breen M, Chowdhary BP, Hirota K, Lear $\mathrm{T}$, et al: International system for cytogenetic nomenclature of the domestic horse. Chromosome Res 5:433-443 (1997).

Bozsaky E, Czimber G, Kovacs A: The XO-syndrome in mares - literature review and preliminary report of a case. Hung J Anim Prod 52: 144-150 (2003)

Bugno M, Slota E: Application of arm-specific painting probes of horse $\mathrm{X}$ chromosome for karyotype analysis in an infertile hutsul mare with 64,XX/65,XX+Xp karyotype: case report. Acta Vet Hung 55:309-314 (2007)

Bugno M, Slota E, Tischner M, Kozubska-Sobocinska A: A case of $64, \mathrm{XX} / 64, \mathrm{XY}$ leucocytic chimerism in a fertile mare of the Wielkopolska breed. Ann Anim Sci 26:9-16 (1999).

Bugno M, Slota E, Zabek T: Two cases of subfertile mares with 64,XX/63,X mosaic karyotype. Ann Anim Sci 1:7-11 (2001)

Bugno M, Klukowska J, Slota E, Tischner M, Switonski M: A sporadic case of the sex-reversed mare (64,XY; SRY-negative): molecular and cytogenetic studies of the $\mathrm{Y}$ chromosome. Theriogenology 59:1597-1603 (2003a).

Bugno M, Slota E, Tischner M, Tischner M: X chromosome monosomy as one of the reasons for reduced fertility or infertility in the mare. Ann Anim Sci 3:207-212 (2003b).
Bugno M, Slota E, Wieczorek M, Yang F, Buczynski J, Switonski M: Non-mosaic X-trisomy, detected by chromosome painting, in an infertile mare. Equine Vet J 35:209-210 (2003c).

Bugno M, Slota E, Pienkowska-Schelling A, Schelling C: An effective method to diagnose X chromosome aneuploidy - the most frequent aberration in the horse. Rocz Nauk Zoot 32:1117 (2005).

Bugno M, Pienkowska-Schelling A, Schelling C, Wlodarczyk N, Slota E: Utilization of the probe generated by chromosome microdissection, for detection of equine X chromosome aneuploidy. Ann Anim Sci 6:205-210 (2006).

Bugno M, Slota E, Koscielny M: Karyotype evaluation among young horse populations in Poland. Schweiz Arch Tierheilk 149:227-232 (2007a).

Bugno M, Slota E, Pienkowska-Schelling A, Schelling C: Detection of equine X chromosome mosaicism in a mare using an equine $\mathrm{X}$ whole chromosome painting probe (WCPP) case report. Acta Vet Hung 55:207-213 (2007b).

Chaves R, Adega F, Heslop-Harrison JS, GuedesPinto $\mathrm{H}$, Wienberg J: Complex satellite DNA reshuffling in the polymorphic $t(1 ; 29)$ Robertsonian translocation and evolutionary derived chromosomes in cattle. Chromosome Res 11: 641-648 (2003a).

Chaves R, Adega F, Wienberg J, Guedes-Pinto H, Heslop-Harrison JS: Molecular cytogenetic analysis and centromeric satellite organization of a novel 8;11 translocation in sheep: a possible intermediate in biarmed chromosome evolution. Mamm Genome 14:706-710 (2003b).

Chaves R, Guedes-Pinto H, Heslop-Harrison IS Phylogenetic relationships and the primitive $\mathrm{X}$ chromosome inferred from chromosomal and satellite DNA analysis in Bovidae. Proc Biol Sci 272 (1576):2009-2016 (2005)

Chowdhary BP: Cytogenetics and physical chromosome maps, in Rothschild MF, Ruvinsky A (eds): The Genetics of the Pig, pp 199-264 (CABI, Oxon 1998)

Christensen K, Agerholm JS, Larsen B: Dairy breed bull with complex chromosome translocation: Fertility studies. Hereditas 117: 199-202 (1992).

Coates JW, Schmutz SM, Rousseaux CG: A survey of malformed aborted bovine fetuses, stillbirths and non-viable neonates for abnormal karyotypes. Can J Vet Res 52:258-263 (1988).

Danielak B, Kozubska-Sobocinska A, Slota E, Slawomirski J: Karyotype 61,XXY in a young bull of Polish Red Breed. Rocz Nauk Zoot 15:7-14 (1988).

Danielak-Czech B, Kozubska-Sobocinska A, Slota E, Rejduch B, Kwaczynska A: Preliminary identification of pair 1 chromosome rearrangement in the Polish Landrace sow. Arch Zootec 45: 215-219 (1996)

Danielak-Czech B, Switonski M, Slota E: First identification of reciprocal translocations in Polish pigs. J Anim Breed Genet 114:69-78 (1997).

Darré R, Quéinnec G, Berland HM: La translocation $1 / 29$ chez les bovins. Etude générale et importance dans le Sud-Ouest. Rev Méd Vét 123: 477-494 (1972a).

Darré R, Quéinnec G, Berland HM: Diagnostic précoce du freemartinisme et chimérisme leucocytaire des veaux jumeaux hétérosexués. Rev Med Vét 123:1-17 (1972b)

Darré R, Berland HM, Goustat P: Statut chromosomique des populations de sangliers sauvages et d'élevages en France. Rev Méd Vét 143:225232 (1992).
De Giovanni A, Succi G, Molteni L, Castiglioni M: A new autosomal translocation in 'Alpine grey cattle’. Ann Genet Sel Anim 11:115-120 (1979).

Di Meo GP, Molteni L, Perucatti A, De Giovanni A, Incarnato $\mathrm{D}$, et al: Chromosomal characterization of three centric fusion translocations in cattle using G-, R- and C-banding and FISH technique. Caryologia 53:213-218 (2000).

Di Meo GP, Perucatti A, Floriot S, Incarnato D, Rullo $\mathrm{R}$, et al: Chromosome evolution and improved cytogenetic maps of the $\mathrm{Y}$ chromosome in cattle, zebu, river buffalo, sheep and goat. Chromosome Res 13:349-355 (2005)

Di Meo GP, Perucatti A, Chaves R, Adega F, De Lorenzi L, et al: Cattle $\operatorname{rob}(1 ; 29)$ originating from complex chromosome rearrangements as revealed by both banding and FISH-mapping techniques. Chromosome Res 14:649-655 (2006).

Ducos A, Dumont P, Séguéla A, Pinton A, Berland $\mathrm{HM}$, et al: A new reciprocal translocation in a subfertile bull. Genet Sel Evol 32:589-598 (2000).

Ducos A, Pinton A, Yerle M, Séguéla A, Berland HM, et al: Cytogenetic and molecular characterization of 8 new reciprocal translocations in the pig species. Estimation of their incidence in the French populations. Genet Sel Evol 34:389406 (2002).

Ducos A, Pinton A, Berland HM, Calgaro A, BrunBaronnat $C$, et al: Cleft palate associated with an unbalanced karyotype in piglets sired by a boar heterozygous carrier of a balanced constitutional reciprocal translocation. Vet Rec 154 659-661 (2004)

Ducos A, Berland HM, Bonnet N, Calgaro A, Billoux S, et al: Chromosomal control of pig populations in France: 2002-2006 survey. Genet Sel Evol 39:583-597 (2007)

Dutrillaux B, Laurent C, Couturier J, Lejeune J: Coloration des chromosomes humains par l'acridine orange après traitement par le 5bromodeoxyuridine. C R Acad Sci (Paris) 276: 3179-3181 (1973)

Ford CE, Pollock DL, Gustavsson I: Proceedings of the First International Conference for the Standardisation of Banded Karyotypes of Domestic Animals. University of Reading Reading, England, 2nd-6th August 1976. Hereditas 92:145162 (1980).

Fries R, Popescu P: Cytogenetics and physical chromosome maps, in Fries R, Ruvinsky A (eds) The Genetics of Cattle, pp 247-327 (CABI, New York 1999).

Gersen SL: History of clinical cytogenetics, in Gersen S, Keagle M (eds): The Principles of Clinical Cytogenetics, pp 3-9 (Humana Press, Totowa 1999).

Gustavsson I: Cytogenetics, distribution and phe notypic effects of a translocation in Swedish cattle. Hereditas 63:68-169 (1969).

Gustavsson I: Chromosomes of repeat-breeder heifers. Hereditas 68:331-332 (1971).

Gustavsson I: Chromosome aberrations and their influence on the reproductive performance of domestic animals - a review. Z Tierz Züchtungsbiol 97:176-195 (1980).

Gustavsson I: Standard karyotype of the domestic pig. Hereditas 109:151-157 (1988).

Gustavsson I, Kovacs A: The translocation 1/29 in Swedish Red and White cows imported from Sweden to Hungary. Proceedings of the $3^{\text {rd }} \mathrm{Eu}-$ ropean Colloquium on Cytogenetics of Domestic Animals 535 (1977)

Gustavsson I, Rockborn G: Chromosome abnormality in three cases of leukaemia in cattle. $\mathrm{Na}$ ture 203:990 (1964) 
Hayes H, Di Meo GP, Gautier M, Laurent P, Eggen A, Iannuzzi L: Localization by FISH of the 31 Texas nomenclature type I markers to both Qand R-banded bovine chromosomes. Cytogenet Cell Genet 90:315-320 (2000).

Henricson B, Bäckström L: Translocation heterozygosity in a boar. Hereditas 52:166-170 (1964).

Hidas A, Szalay I, Liptoi K, Varkonyi E: Cytogenetic analysis of early dead embryos in chicken breeding stocks. Arch Zootec 45:221-224 (1996).

Iannuzzi L: G- and R-banded prometaphase karyotypes in cattle (Bos taurus L.). Chromosome Res 4:448-456 (1996).

Iannuzzi L: Animal cytogenetics and karyotype evolution in bovids. Chromosome Res 15 (suppl 1):3 (2007).

Iannuzzi L, Rangel-Figueiredo T, Di Meo GP, Ferrara L: A new Robertsonian translocation in cattle, rob $(15 ; 25)$. Cytogenet Cell Genet 59: 280-283 (1992).

Iannuzzi L, Rangel-Figueiredo T, Di Meo GP, Ferrara L: A new centric fusion translocation in cattle, $\operatorname{rob}(16 ; 18)$. Hereditas 119:239-243 (1993).

Iannuzzi L, Di Meo GP, Perucatti A, Incarnato D, Schibler L, Cribiu EP: Comparative FISH mapping of bovid X chromosomes reveals homologies and divergences between the subfamilies Bovinae and Caprinae. Cytogenet Cell Genet 89:171-176 (2000)

Iannuzzi L, Di Meo GP, Perucatti A, Incarnato D, Molteni L, et al: A new balanced autosomal reciprocal translocation in cattle revealed by banding techniques and HSA-painting probes. Cytogenet Cell Genet 94:225-228 (2001a).

Iannuzzi L, Molteni L, Di Meo GP, De Giovanni A, Perucatti A, et al: A case of azoospermia in a cattle bull carrying an Y-autosome reciprocal translocation. Cytogenet Cell Genet 95:225227 (2001b).

Iannuzzi L, Di Meo GP, Perucatti A, Eggen A, Incarnato D, et al: A pericentric inversion in cattle Y-chromosome. Cytogenet Cell Genet 94:202205 (2001c)

ISCNDA 1989: International System for Cytogenetic Nomenclature of Domestic Animals. Di Berardino D, Hayes $\mathrm{H}$, Fries R, Long S (eds). Cytogenet Cell Genet 53:65-79 (1990).

ISCNDB 2000: International System for Cytogenetic Nomenclature of Domestic Animals. Di Berardino D, Di Meo GP, Gallagher DS, Hayes $\mathrm{H}$ Iannuzzi L (eds). Cytogenet Cell Genet 92:283299 (2001).

Jaszczak K, Parada R, Wardecka B, Niemczewski C: A note on analysis of chromosome constitution in tissues, quality of semen and DNA microsatellite loci in bull with 60,XY/61,XXY karyotype. J Anim Feed Sci 12:521-527 (2003).

Joerg H, Garner D, Rieder S, Suwattana D, Stranzinger G: Molecular genetic characterization of Robertsonian translocations in cattle. J Anim Breed Genet 118:371-377 (2001).

Keszka J, Jaszczak K: The frequency of chromosomal XX/XY chimerism occurrence in Merino Booroola sheep. J Appl Genet 37:367-372 (1996).

King WA: Chromosome abnormalities and pregnancy failure in domestic animals. Adv Vet Sci Comp Med 34:229-250 (1990).

Kovacs A: Occurrence of the $1 / 29$ translocation in the Hungarian Grey cattle. Ann Génét Sél Anim 10:594 (1978).

Kovacs A: Application of cytogenetics to cattle breeding improvement, in Halnan CRE (ed) Cytogenetics of Animals (CABI, Wallingford 1989).

Kovacs A: Fertility and milk production of cattle carrying the 1:29 chromosome translocation. Hung J Anim Prod 43:155-181 (1994).
Kovacs A, Csukly S: Effect of the 1/29 translocation upon fertility in Hungarian Simmental cattle. Proceedings of the $4^{\text {th }}$ European Colloquium on Cytogenetics of Domestic Animals, Uppsala, Sweden, pp 35-43 (1980).

Kovacs A, Szepeshelyi F: Chromosomal screening of breeding bulls in Hungary. J Dairy Sci 70 (suppl 1):236 (1987)

Kovacs A, Meszaros I, Sellyei M, Vass L: Mosaic centromeric fusion in a Holstein-Friesian bull. Acta Biol Hung 24:215-220 (1973).

Kovacs A, Stukovszky J, Gippert E, Csontos G, Nagy J: Single-born XX/XY chimaeric bulls with normal phenotype. Ann Génét Sél Anim 9:533 (1977).

Kovacs A, Villagomez DAF, Gustavsson I, Lindblad K, Foote RH, Howard TH: Synaptonemal complex analysis of a three breakpoint translocation in a bull. Cytogenet Cell Genet 61:195-201 (1992a).

Kovacs A, Gustavsson I, Csukly S, Karakas P: Lifetime production of Simmental cows carrying the 1;29 translocation. $10^{\text {th }}$ European Colloquium on Cytogenetics of Domestic Animals, Utrecht, The Netherlands, pp 121-125 (1992b).

Krumrych W: A case of new XXY trisomy in a bull. Med Weter 59:506-509 (2003).

Krumrych W, Jaskowski JM, Gehrke M, Zbylut J: First case of 61,XYY trisomy in bull in Poland - initial observations. Bull Vet Inst Pulawy 46:307-315 (2002).

Kubien E, Pozor M, Tischner M: A case of horse with 65,XXY karyotype. Appl Biol Comm suppl 1:29 (1991).

Kuokkanen MT, Mäkinen A: A reciprocal translocation $(7 \mathrm{q}-; 12 \mathrm{q}+)$ in the domestic pig. Hereditas 106:147-149 (1987).

Kuokkanen MT, Mäkinen A: Reciprocal chromosome translocations $(1 \mathrm{p}-; 11 \mathrm{q}+)$ and $(1 \mathrm{p}+; 15 \mathrm{q}-)$ in domestic pigs with reduced litter size. Hereditas 109:69-73 (1988).

Legault C, Popescu CP: Les translocations réciproques chez le porc domestique: détection, éradication et prévention. Elevage Insémination 254:1-12 (1993).

Lejeune J, Gautier M, Turpin R: Etude des chromosomes somatiques de neuf enfants mongoliens. CR Acad Sci (Paris) 248:1721-1722 (1959).

Lejeune J, Lafourcade J, Berger R, Vialatte J, Boeswillwald M, et al: Trois cas de délétion partielle d'un bras court d'un chromosome 5. CR Acad Sci (Paris) 257:3098-3102 (1963).

Liptoi K, Hidas A, Rouvier R: Investigations of chromosome abnormalities and early embryonic mortality in goose lines. Acta Biol Hung 56:53-65 (2005).

Lloyd DC, Edwards AA, Leonard A, Deknudt GL Verschaeve L, et al: Chromosomal aberrations in human lymphocytes induced in vitro by very low doses of X-rays. Int J Radiat Biol 61:335-343 (1992).

Long SE: Reciprocal translocations in the pig (Sus scofa): a review. Vet Rec 128:275-278 (1991)

Mäkinen A, Remes E: Low fertility in pigs with $\mathrm{rcp}(4 \mathrm{q}+; 13 \mathrm{q}-)$ translocation. Hereditas 104: 223-229 (1986).

Mäkinen A, Pitkanen T, Andersson M: Two cases of reciprocal translocations in domestic pigs producing small litters. J Anim Breed Genet 114: 377-384 (1997).

Mäkinen A, Andersson M, Hakkinen A, Kuosmanen S: A reciprocal translocation between autosomes 8 and 10 in a boar used for artificial insemination service and its effects on litter size. Anim Reprod Sci 56:237-243 (1999a).

Mäkinen A, Hasegawa T, Makila M, Katila T: Infertility in two mares with XY and XXX sex chromosomes. Equine Vet J 31:346-349 (1999b).
Mäkinen A, Katila T, Andersson M, Gustavsson I: two sterile stallions with XXY-syndrome. Equine Vet J 32:358-360 (2000).

Mäkinen A, Hasegawa T, Syrja P, Katila T: Infertile mares with $\mathrm{X} 0$ and $\mathrm{XY}$ sex chromosome deviations. Equine Vet Educ 18:60-62 (2006).

Molteni L, Perucatti A, Iannuzzi A, Di Meo GP, De Lorenzi L, et al: A new case of reciprocal translocation in a young bull: $\operatorname{rcp}(11 ; 21)(\mathrm{q} 28 ; \mathrm{q} 12)$ Cytogenet Genome Res 116:80-84 (2007).

Nicolae I: The dicentric chromosome in cattle. Ann Genet 46:97 (2003).

Nicolae I, Livescu BE: A rare chromosomal aberration type: tandem translocation. Arch Zootec 3: 41-46 (1995).

Nicolae I, Popescu CP: Cytogenetic studies on Romanian cattle breeds. Arch Zootec 50:355-361 (2001).

Nicolas N, Hidas A, Renaville R, Kettman R, Gengler N, et al: Probable absence of the 1/29 Robertsonian translocation in the Belgian Blue breed of cattle. Genet Sel Evol 27:377-380 (1995).

Nowacka J, Switonski M, Mackowski M, Slota E, Radko A, Zabek T: The ambiguity of freemartinism diagnosis in cattle revealed by cytogenetic and molecular techniques. Czech J Anim Sci 49:239-243 (2004).

Nowacka J, Urbaniak K, Antosik P, Jaskowski JM Frackowiak H, Switonski M: Polymelia associated with frequent chromosome breaks in a heifer. Vet Rec 161:276-277 (2007).

Nowell PC, Hungerford DA: A minute chromosome in human chronic granulocytic leukemia. Science 132:1497 (1960).

Padula AM: The freemartin syndrome: an update. Anim Reprod Sci 87:93-109 (2005).

Parada R, Jaszczak K, Sysa P: Cytogenetic study of mares with altered fertility. Prace i Materiały Zootechniczne 48:71-81 (1999).

Pascual I, Arruga MV: Detection and localization of chromosomal aberrations in sheep (Ovis aries). Cytogenet Cell Genet 74:237-238 (1996).

Pawlak M, Rogalska-Niznik N, Cholewinski G, Switonski M: Study on the origin of $64, \mathrm{XX} / 63, \mathrm{X}$ karyotype in four sterile mares. Vet Med Czech 45:299-305 (2000)

Payan-Carreira R, Pires MA, Quaresma M, Chaves $\mathrm{R}$, Adega $\mathrm{F}$, et al: A complex intersex condition in a Holstein calf. Anim Reprod Sci 103:154163 (2008).

Pinton A, Pailhoux E, Piumi F, Rogel-Gaillard C, Yerle $\mathrm{M}$, et al: A case of intersexuality in pigs associated with a de novo paracentric inversion 9(p1.2;p2.2). Anim Genet 33:69-71 (2002).

Pinton A, Faraut T, Yerle M, Gruand J, Pellestor F, Ducos A: Comparison of male and female meiotic segregation patterns in translocation heterozygotes: a case study in an animal model (Sus scrofa domestica L.). Hum Reprod 20: 2476-2482 (2005).

Pinton A, Raymond-Letron I, Berland HM, Bonnet N, Calgaro A, et al: Meiotic studies in an azoospermic $(Y ; 14)$ translocated boar. Chromosome Res 15(suppl 1):149 (2007).

Pliska V, Stranzinger G: Farm Animals in Biomedical Research (Verlag Paul Parey, HamburgBerlin 1990).

Popescu CP: Deux cas nouveaux de fusion centrique chez les bovines. Ann Génét Sél Anim 3: 521-526 (1971)

Popescu CP, Legault C: Une nouvelle translocation réciproque $\mathrm{t}(4 \mathrm{q}+; 4 \mathrm{q}-)$ chez le porc domestique (Sus scrofa domestica). Ann Génét Sél Anim 11: 361-369 (1979).

Popescu CP, Bonneau M, Tixier M, Bahri I, Boscher J: Reciprocal translocations in pigs. J Hered 75: 448-452 (1984) 
Popescu CP, Long S, Riggs P, Womack J, Schmutz S, et al: Standardization of cattle karyotype: Report of the committee for the standardization of the cattle karyotype. Cytogenet Cell Genet 74:259-261 (1996).

Rangel-Figueiredo T, Iannuzzi L: High incidence of $1 / 29$ centric fusion translocation in a Portuguese cattle breed. J Genet Breed 44:203-206 (1990).

Rangel-Figueiredo T, Iannuzzi L: Frequency and distribution of rob $(1 ; 29)$ in three Portuguese cattle breeds. Hereditas 119:233-237 (1993).

Refsdal AO: Low fertility in daughters of bulls with 1/29 translocation. Acta Vet Scand 17:190-195 (1976).

Rejduch B, Slota E, Switonski M: Cytogenetic analysis of beef cattle. Genet Pol 35:323-332 (1994).

Rejduch B, Jazdzewski J, Słota E, Kozubska-Sobocinska A, Danielak-Czech B: Evaluation of reproductive performance on the basis of semen analysis in the bulls carrying $60, \mathrm{XX} / 60, \mathrm{XY}$ chimerism. Hung J Anim Prod 48:110-111 (1999).

Rejduch B, Słota E, Gustavsson I: Chimerism in the germ cell line of mature bulls born in heterosexual twinning. Theriogenology 54:621-627 (2000).

Rejduch B, Slota E, Sysa P, Kwaczynska A, Kozubska-Sobocinska A, Danielak-Czech B: Diagnosis of a new reciprocal translocation $\operatorname{rcp}(9 ; 14)$ (q14;q23) in infertile boar after the synaptonemal complex analysis. Ann Anim Sci 3:269-278 (2003).

Rejduch B, Kozubska-Sobocinska A, Radko A, Rychlik T, Slota E: The application of genetic markers for cell chimerism diagnosis in lambs. J Anim Breed Genet 121:197-203 (2004).

Rho GJ, Coppola G, Sosnowski J, Kasimanickam R, Johnson WH, et al: Use of somatic cell nuclear transfer to study meiosis in female cattle carrying a sex-dependent fertility-impairing X-chromosome abnormality. Cloning Stem Cells 9: 118-129 (2007).

Roux C, Tripogney C, Morel F, Joanne C, Fellmann F, et al: Segregation of chromosomes in sperm of Robertsonian translocation carriers. Cytogenet Genome Res 111:291-296 (2005).

Rychlik T, Kozubska-Sobocinska A, Rejduch B, Sikora J: The phenomenon of cell chimerism in goats. Vet Med Czech 50:311-314 (2005).

Santos S, Chaves R, Adega F, Bastos E, Guedes-Pinto $\mathrm{H}$ : Amplification of the major satellite DNA family (FA-SAT) in a cat fibrosarcoma might be related to chromosomal instability. J Hered 97: 114-118 (2006)

Schmutz SM, Moker J: Impact of a 1;29 Robertsonian translocation on a herd of purebred beef cattle. Can J Anim Sci 69:891-896 (1989).
Schmutz SM, Flood PF, Moker JS, Barth A, Mapletoft RJ, Cates W: Incidence of chromosomal anomalies among western Canadian beef cattle. Can J Anim Sci 70:779-783 (1990).

Schmutz SM, Moker JS, Barth AD, Mapletoft RJ: Embryonic loss in superovulated cattle caused by the 1;29 Robertsonian translocation. Theriogenology 35:705-714 (1991).

Schmutz SM, Moker JS, Clark EG, Orr JP: Chromosomal causes of spontaneous abortion and neonatal loss in cattle. J Vet Clin Invest 8:91-95 (1996).

Schmutz SM, Moker JS, Pawlyshyn V, Haugen B, Clark EH: Fertility effects of the 14;20 Robertsonian translocation in cattle. Theriogenology 47:815-823 (1997).

Seabright M: A rapid banding technique for human chromosomes. Lancet 2:971-972 (1971).

Slota E, Switonski M: A new Robertsonian translocation 5;22 in cattle. Studies of banded chromosomes and synaptonemal complexes. Genet Pol 33:227-231 (1992).

Slota E, Sysa PS, Janicka-Mazur W: A new case of XX/XXY chimerism in a bull. Genet Pol 23: 249-255 (1982).

Slota E, Danielak B, Kozubska A: Structural rearrangement of metacentric chromosomes in the ram of Polish wrzosówka breed. Proceedings of the $7^{\text {th }}$ European Colloquium on Cytogenetics of Domestic Animals, Warsaw, Poland, p 37 (1986).

Slota E, Danielak B, Kozubska A: The Robertsonian translocation in cattle quintuplets. Proceedings of the $8^{\text {th }}$ European Colloquium on Cytogenetics of Domestic Animals, Bristol, UK, pp 122-124 (1988)

Slota E, Kozubska-Sobocinska A, Koscielny M, Danielak-Czech B, Rejduch B: Detection of the $\mathrm{XXY}$ trisomy in a bull by using sex chromosome painting probes. J Appl Genet 44:379-382 (2003).

Slota E, Kozubska-Sobocinska A, Danielak-Czech B, Rejduch B, Kowol P, Zyga A: A note on cytogenetic monitoring of Polish Red cattle. J Anim Feed Sci 13:65-71 (2004).

Stranzinger GF, Forster M: Autosomal chromosome translocation of piebald cattle and brown cattle. Experientia 15:24-27 (1976).

Switonski M: A pericentric inversion in an X chromosome in the cow. J Hered 78:58-59 (1987).

Switonski M: Paracentric inversion involving NOR of chromosome 8 in a boar: studies of synaptonemal complexes under a light microscope. Genet Sel Evol 23:181-189 (1991).
Switonski M, Chmurzynska A, Szczerbal I, Lipczynski A, Yang F, Nowicka-Posluszna A: Sex reversal syndrome $(64, \mathrm{XY}$ : SRY-positive) in a mare demonstrating masculine behaviour. J Anim Breed Genet 122:60-63 (2005).

Sysa PS, Slota E: The XXY syndrome in cattle. Proceedings of the $6^{\text {th }}$ European Colloquium on Cytogenetics of Domestic Animals, Zürich Switzerland, pp 120-128 (1984).

Sysa PS, Slota E, Kiec W: The masculinization of gonads and genital tract in sheep $(54, \mathrm{XX} /$ 54,XY). Cytogenet Cell Genet 74:242 (1996).

Sysa P, Jedryczko R, Slota E: Evaluation of economic effects of bulls cytogenetic control in Poland in the last decade. Chromosome Res 10:28 (2002).

Szatkowska I, Switonski M: Evidence on hereditary occurrence of placental anastomoses in heterosexual twins in sheep. Hereditas 124:107-110 (1996).

Szczerbal I, Stefaniak T, Dubiel A, Siembieda J, Nizanski W, Switonski M: Chromosome instability in a calf with amelia of thoracic limbs. Vet Pathol 43:789-792 (2006).

Thomas R, Smith KC, Ostrander EA, Galibert F, Breen M: Chromosome aberrations in canine multicentric lymphomas detected with comparative genomic hybridisation and a panel of single locus probes. Br J Cancer 89:1530-1537 (2003).

Thomas R, Smith KC, Ostrander EA, Galibert F, Breen M: Chromosome aberrations in canine multicentric lymphomas detected with comparative genomic hybridisation and resolution BAC microarray for CGH analysis of canine tumors. Genome Res 15:1831-1837 (2005).

Tozser J, Domokos Z, Renaville R, Mezes M, Hidas A, Nagy A: Reproductive biological status in Charolais sire candidates and its integration into the selection index. Hung J Anim Prod 44: 109-122 (1995).

Tschudi P: 12 years of cytogenetic investigations in AI bulls in Switzerland. Proceedings of the 6 th European Colloquium on Cytogentics in Domestic Animals, Zurich, Switzerland, pp 40-42 (1984).

Villagomez DAF, Andersson M, Gustavsson I, Plöen L: Synaptonemal complex analysis of a reciprocal translocation, $\mathrm{rcp}(20 ; 24)$ (q17;q25), in a subfertile bull. Cytogenet Cell Genet 62:124130 (1993).

Weigel KA: Prospects for improving reproductive performance through genetic selection. Anim Reprod Sci 96:323-330 (2006).

Wieczorek M, Switonski M, Yang F: A low-level Xchromosome mosaicism in mares, detected by chromosome painting. J Appl Genet 44:525527 (2001). 